\title{
Does Investment in Advertising Boost Economic Performance? Firm-Level Evidence of Ecuadorian Manufacturing ${ }^{\star *}$
}

\author{
Segundo Camino-Mogro ${ }^{1^{*}}$
}

\begin{abstract}
This paper examines how the firm's advertising investments are related to different measures of economic and productivity performance during 2007 - 2017 in Ecuadorian manufacturing. Particularly, this study analyzes if firms that have advertising investments have better economic and productivity performance compare to non-advertising investment firms. In addition, this looks for evidence on how the different advertising strategies may affect productivity and gross revenue in both advertising and non-advertising firms. For this, this paper estimates the total factor productivity (TFP) at firm-level using a semi-parametric approach to reduce the simultaneous and endogeneity problems in the selection of inputs. The estimation results show that manufacturing firms which invest in advertising have an Advertising Premia on economic and productivity indicators, this premia is higher on economic outcomes. Also, the findings are that continuing advertising investment strategy firms have higher TFP, labor productivity, and gross revenue than exiting advertising investment firms, suggesting self-selection in the exit side of the market but not in the entry side of the market. Finally, the study finds that after firms entering to invest in advertising, firms experience an improvement on TFP, labor productivity, and gross revenue growth, which are in favor of learning by advertising hypothesis.
\end{abstract}

Keywords: Productivity; advertising; firm strategy; intangible capital

Submitted: March 27 $7^{\text {th }}, 2019$ / Approved: November $8^{\text {th }}, 2019$

\section{Introduction}

Firms usually seek to have economic returns/profitability to be able to remain and growth in time. In this long-run objective, they invest in tangible and intangible assets/capital, so that, from this firm's assets/ capital, they can operate and produce a good/service that is consumed by the market in which it operates. It is well known that firms that invest in tangible assets/capital, such as machinery and equipment, new factories, and others, do so to increase the production level and thus increase their sales, profitability, and, if possible, market share. However, investments in intangible assets/capital such as Research and Development (R\&D), patents, intellectual property rights, trademarks, goodwill, advertising, and others, may lead to generate the same profitability, sales, productivity and growth levels in market share, see for example: (Corchón \& Marini, 2018; Hall, Mairesse, \& Mohnen, 2010; Lev, 2005). In this final line, Bontempi \& Mairesse (2015) find that intangible capital represents more than four times the productivity gains of tangible capital, similar results are found by Crass \& Peters (2014) where intangible assets, especially R\&D, advertising spending and human capital, improves business productivity.

Advertising spending, as part of the investment in firm intangible assets, is important because it might attract new consumers and also retain current consumers. Aaker \& Myers (1987), Kirmani \& Zeithaml (1993) mention that advertising investments also increases differentiation and awareness; Mizik \& Jacobson (2003), Frieder \& Subrahmanyam (2005) argue that this expenditure creates brand equity, an intangible market-based asset, Fombrun, Gardberg, \& Barnett (2000) state that it also increases reputational capital and this will positively affect the creation of brand equity. In addition, much evidence su- ggests that this investment has a positive effect on a firm's market value (Connolly \& Hirschey, 1984; Salinger, 1984; Chauvin \& Hirschey, 1993; Joshi \& Hanssens, 2010; Luo \& de Jong, 2012).

In this line, firms invest in advertising not only for the mentioned above but also because it could increase sales, profitability, and productivity. Joshi \& Hanssens (2010) mention that "a higher profit in one period may lead to increased advertising budgets, which in turn may boost sales and future profits". If firms start to obtain greater profits, it probably creates an increase in economic performance by investing in new technologies, for example. This increase may lead to generate a greater labor supply. Therefore, an optimal selection of productive factors such as labor and capital will make firms more productive. Also, Chauvin \& Hirschey (1993) mention that spending in advertising can be viewed as a form of investment in intangible assets with predictably positive effects on future cash flows. Nevertheless, they suggest that the potential in the effectiveness of advertising expenditures depends on firm size.

In this line, Chen \& Waters (2017) argue that a highly productive firm may be able to extend its market share with advertising. Overall, the effects of advertising investment in economic performance not only depend on the intensity of the expenditure as the seminal research developed by Dorfman \& Steiner (1954), it also depends on other variables such as: firm size, location, foreign direct investment (FDI) flows, economic sector, and strategies of advertising investments. In addition, firms that invest in advertising create expectations in their consumers, and their demand could rise (Jaumandreu \& Mairesse, 2017), in turn, to satisfy the increase of demand the firms need to be more productive in order to expand their supply and compensate

1) Universidad Complutense de Madrid; Universidad Ecotec; ESAI Business School, Universidad Espíritu Santo - Ecuador and Superintendencia de Compañías, Valores y Seguros.

*Corresponding author: scaminom@supercias.gob.ec

**The author acknowledges funding from the Spanish Ministry of Economy and Competitiveness (project ECO2017-82445-R) 
the emerging demand. Dorfman \& Steiner (1954) analyze how a firm can influence the demand for its products to maximize its profits by choosing the price and the amount of its advertising budget. However, decisions about advertising investment are related to productivity and economic performance in a two-way relation.

Contributing to this empirical debate, this paper gives new insights into the effect of investments in advertising and various measures of productivity and economic performance in the Ecuadorian manufacturing sector during 2007 - 2017 using an underexplored and novel firm-level data. Although, this causal relationship has been studied in developed countries (specifically with a set of intangible assets), scarce evidence has been obtained in developing countries and nothing for Latin American firms.

Ecuador is used as a case study, particularly since it is a dollarized country and where the investment in advertising of manufacturing firms is relatively high since more than $70 \%$ of companies throughout the industry invest in advertising during the period 2007 - 2017. Additionally, the investment in advertising can be seen as an investment in intangible assets that promotes the innovation of a product and that in its effect can produce increases in productivity and economic performance; also as innovation in marketing which refers a new marketing method involving significant changes in product design or packaging, product placement, product promotion or pricing (OECD, 2005), this final concept is scarce addressed in emerging and Latin American economies, because scarce literature analyze this problematic (advertising - productivity) in economic aspect. On the other hand, and generally, advertising has been focused as an expense in most developing countries (contrary to the OECD concept), in this study it is analyzed as an investment in the short and medium-term.

First, this paper determines the advertising premia in firm performance using a firm-level dataset of Ecuadorian manufactures from 2007 - 2017, whereas many previous studies in other countries have employed industry-level data. The data used is obtained from the "Superintendencia de Compañías, Valores y Seguros del Ecuador (SCVS)" which is the supervisory institution of all companies in Ecuador, for this study uses all the manufacturing firms. Second, it estimates the total factor productivity (TFP) to determine the advertising premia on TFP, and then we compare this premium with labor productivity and gross revenue. The TFP is estimated using parametric and semi-parametric techniques. We prefer Levinsohn \& Petrin (2003) estimator, which reduces the endogeneity and simultaneity in the selection of the inputs. Finally, the paper proposes the analysis of advertising investment strategies close to Fariñas \& Martín-Marcos (2007) approach where they use exports strategies, this novel form of studying the advertising investments would help to interpret in a better way which firms have better productivity and economic performance depending on their advertising strategies over time.

In this context, the research objectives are to determine if firms that have advertising investments, measured as marketing innovation similarly to OECD (2005), have better economic and productivity performance compare to non-advertising investment firms. Also, this paper looks for evidence on how the different advertising strategies may affect productivity and gross revenue in both advertising and non-advertising firms.

The structure of the document is as follows: Section 2 shows the literature review and hypotheses; section 3 reviews the methodology and data; section 4 shows the empirical results and discussion; finally, section 5 gives final remarks.

\section{Literature Review and hypotheses}

Research on the effect of advertising investment has focused particularly on the relationship between profitability and sales, although these variables are used as business performance. Studies regarding the relationship between advertising investment and productivity are scarce; mostly, it has been made as an intangible asset where it is included as brand capital, marketing capital, or even as R\&D.

Many studies find that firms which invest in advertising show a positive effect on their performance and profitability (Comanor \& Wilson, 1974; Porter, 1974; Lambin, 1976; Kirmani \& Wright, 1989; Erickson, 1992; Leone, 1995; Mela, Gupta, \& Lehmann, 1997; Osinga, Leeflang, Srinivasan, \& Wieringa, 2011; Chen \& Waters, 2017). However, there are also other studies testing the relationship between advertising and firm performance, that are unable to find a clear direction of the relation (Erickson \& Jacobson, 1992; Han \& Manry, 2004; Joshi \& Hanssens, 2009). Besides, there are a few studies that have found no relation between advertising investment and sales performance (Kihlstrom \& Riordan, 1984; Milgrom \& Roberts, 1986; Mesak, 1992; Hanssens, Parsons, \& Schultz, 1999; Ali Shah \& Akbar, 2008)

In this line, although it may seem obvious that firms invest in advertising to improve their performance and specifically sales and profitability, this does not always happen, particularly because the effects of this investment are not always accompanied by goods improvements, training of employees, labor and business productivity, among other facts. Authors like Narayanan, Desiraju, \& Chintagunta (2004), Kremer, Bijmolt, Leeflang, \& Wieringa (2008), Osinga, Leeflang, Srinivasan, \& Wieringa (2011) refer that advertising does not necessarily generate an expected sales return, rather it has a moderate influence on short- and long-run sales; the advertising investment takes time for the results to be noticed within-firm performance, it is an adaptive learning process, Hoberg \& Phillips (2016) mention that this could be associated with a later differentiation of the competition which after a while can be translated into profitability; this differentiation with competitors could create endogenous entry barriers as mentioned by Sutton (1991).

It is also important to mention that not all firms have the same returns in advertising investments. Assaf et al. (2015) argue that the link between advertising investment and firm performance is not simple, and, assuming that there are no other variables interacting with this relationship is unrealistic. In this line, firm size is an important variable when analyzing the impact of advertising investments on firm sales and profitability. Another important relationship beyond investment in advertising is the intensity of this investment. Thus, Assaf, 
Josiassen, Mattila, \& Cvelbar (2015), Sun (2014), Eng \& Keh (2007), Chauvin \& Hirschey (1993) found that large firms tend to be advertising-intensive and get better returns in advertising than smaller firms.

However, Dorfman \& Steiner (1954) in their theoretical model, suggest that the advertising-sales ratio equals the product of the price-cost margin and the advertising elasticity of the demand. In this sense, firms need to decide their advertising budget in terms of sales percentage to obtain profits. Martin (1979) takes advantage of this model and shows that the decisión of advertising investment also depends on both profitability and market concentration at the same time, which can be characterized as a quasi-simultaneous decision. Also, he found that firms with a high advertising-sales ratio have better profits. Conversely, Netter (1982) shows that advertising reduces the profitability returns of those firms that advertise intensively.

Other variables affecting advertising investment, and its intensity, are the market size and market growth, for example, firms need to strengthen their advertising strategy when they operate in growing trend markets with a competitive structure ${ }^{1}$. Mavrommati \& Papadopoulos (2005) found that the factors that affect the elasticity of advertising are expected to influence the advertising intensity as well; these factors are associated with the demand, product differentiation, and market conditions.

Jaumandreu \& Mairesse (2017) show the effects of product and process innovation in firms' productivity in which they found that the advertising variable augments the demand significantly. However, if they exclude this advertising variable from the cost equation, they found that there are no significant changes in the marginal cost function, concluding that the effect of advertising upon productivity is indirect. In this sense, the effect of advertising affects not only the current demand but also the future demand, future market share, and profits (Chauvin \& Hirschey, 1993; Baye, Jansen, \& Lee, 1992), which in the end may improve labor and business productivity, in other words the TFP.

Studies related to business productivity and advertising investment are scarce; the closest to the productivity-advertising relationship is when advertising investment is treated as an intangible asset, specifically when this asset is the sum of R\&D and advertising. Corrado, Hulten, \& Sichel (2005) take advertising investment as a brand equity component under the economic competencies group and found that advertising investment is 0.023 times the GDP in the US. This has been the first attempt to include intangible assets as part of the national accounting measurement, and also the first time advertising is treated as an investment and not as an expense. Based on this, Corrado, Hulten, \& Sichel (2009) found that the contribution of intangible capital to growth in labor productivity is about the same as the contribution of tangibles, in addition, the capitalization of intangibles increases the rate of growth of output per hour in both the 1973-95 and 1995-2003 periods. In the same line, Crass, Licht, \& Peters (2015) found that growth in branding capital (as advertising) was associated with a relatively smaller increase in labour productivity growth, it was roughly 0.03 percentage points in manufacturing, utility, and agriculture \& mining, and more or less negligible in the other sectors; Niebel, O’Mahony, \& Saam (2017) found that intangible assets, including advertising, in the European Union (EU) countries have a positive impact on labor productivity, especially in manufacturing sectors.

In terms of TFP, Crass \& Peters (2014) found for German manufacturing and services firms that branding capital was positively related with TFP and the magnitude was similar compared to investments in $\mathrm{R} \& \mathrm{D}$, implying that advertising investment increases the business productivity, they also found that branding capital turns out to be positively related to productivity in all manufacturing and service industries. Furthermore, Bontempi \& Mairesse (2015) included advertising investments into the intangible capital group and mentioned that advertising is the most important of these intangibles; they found that customer capital, which includes advertising investment, is the highest contributor to the TFP in the Italian manufacture market.

In summary, the relationship between advertising investment with sales, business performance, and profitability has been studied in a large majority, although the authors have different criteria on the impact of advertising on economic performance. There are certain similarities such as time is an important factor at the moment to know if it really improves economic performance when the advertising investment is incurred. However, the relation advertising investment and TFP has been little investigated, only focused on intangible assets without showing specific results of the pure effect of advertising investments.

In this sense, this paper seeks to fill this gap in the literature not only by finding the pure effect of advertising investments on productivity, labor productivity, and gross revenue. In addition, this paper explores premias of advertising investments on various economic performance variables, and finally, this study contributes to the existent literature by studying how advertising investments strategies can impact two measures of productivity and its growth rate, and also gross revenue; in addition, we use Ecuador as emerging country since scarce literature on this topic have been studied developing countries and only have focused on developed countries.

Likewise, the paper contributes to the management literature in the sense that not only the effect of advertising investment on economic performance is analyzed, but also, the advertising investment variable being a business and endogenous decision, is the exogeneizes in such a way that different business strategies in advertising investment are analyzed and how these decisions can affect not only productivity and sales but their growth rates in the short and medium run.

We, therefore, formulate the following four hypotheses:

H1: Investments in advertising have a positive relationship with economic and productivity performance; therefore, there is an Advertising Premia.

${ }^{1}$ Conversely, advertising investment may not be necessary under a perfect competition structure as all goods are homogeneous (Tirole, 1988; Sutton, 1991). 
H2: The productivity level is positively affected by advertising investments in such a way that firms that invest in advertising have higher TFP than non-advertising investment firms.

H3: There is self-selection and learning by advertising to invest in advertising since firms adopt different strategies to boost productivity and gross revenue.

H4: Investments in advertising could have a lag effect on economic performance, specifically on sales and productivity.

\section{Empirical Methods}

\subsection{Data Structure}

We use a unique and novel unbalanced panel data from 2007 to 2017 (annually) built with all the population of Ecuadorian manufacturing formal firms, this dataset was constructed from the balance sheets and financial statements registered in the official website of the Superintendencia de Compañías, Valores y Seguros del Ecuador (SCVS) (2018) which is the company supervisory institution in Ecuador ${ }^{2}$.

The dataset provided by the SCVS contains information on firm-level characteristics, geographical location (region, state, and city); industry location (ISIC two Digits to ISIC six digits) in Table 1A I show the 24 ISIC codes according to the manufacturing industry; economic and financial accounts of all formal manufacturing firms. Those characteristics of data allow getting information on gross revenue, net tangible assets, investments, number of formal employees, domestic raw material purchases, foreign raw material purchases and imports, all measures in real values ${ }^{3}$, size measured as an amount of gross revenue and/or number of employees ${ }^{4}$. Also, the dataset contains information about other important accounts such as: expenditure in advertising, if the firm receives Foreign Direct Investment (FDI) on each year, wages, gross profit, and others. Which those variables it is possible to construct some indicators like labor productivity, capital productivity, wages per hour.

The panel data contains 31,064 observations, and 5,371 formal manufacturing firms during 2007 - 2017. This information is given by depuration criteria similar to Camino-Mogro, Armijos-Bravo, \& Cornejo-Marcos (2018) where firms that had reported values less than or equal to 0 in gross revenue, number of workers, total fixed assets and consumption of raw material were eliminated. Also, firms that had reported the number of workers but zero values in wages were eliminated too. Finally, firms that are not active in each year of analysis were eliminated because the supervisory institution does not have the financial statement and balance sheet.

Table 1 shows the definition of each variable included in the analysis. The variables description was made based on the established by the SCVS on its accounts catalog of the Ecuadorian firm system.
Besides, Table 1 shows the mean values for several firm characteristics. The comparison is divided into three groups, advertising spending firms, non-advertising spending firms by size: Micro, Small and Medium (MSME), and large firms, also all firms since 2007. The dataset allows dividing the firms into different strategies that companies have done in terms of advertising investments during the whole period. In this path, firms can be classified into five strategies group: Continuing advertising investments, Entering advertising investments, Switching advertising investments, Exiting advertising investments, Non-advertising investments. Firms investing in advertising the whole period is defined as continuing advertising investments; firms that entry to invest in advertising during the period without further changes in their strategy is defined as entering advertising investments; on the contrary, firms that stop to invest in advertising during the period without further changes in their strategy is defined as exiting advertising investments; firms that switch their advertising investments more than once in the whole period are defined as switching advertising investments; finally, the non-advertising investments corresponds to firms not invests in advertising in all the period.

Table 1 shows the difference between advertising investment firms and non-advertising firms. The main differences between those groups are in terms of size since the disparity is substantial in gross revenue, employment, capital stock, and raw material consumption. The difference in gross revenue is approximately 8.5 times more in advertising investment firms, in employment is 5.6 times, in capital stock is 8.5 times, in raw materials consumption is 7 times and in gross profit is 16.9 times more than their counterparts.

In addition, in productivity indicators, this pattern continues; however, it is slightly lower than for output and input variables. On average, advertising investment firms have more Labor productivity, TFP, Capital per hour $(\mathrm{CPH})$, and wage per hour (WPH) than non-advertising firms. This relation is persistent across firm size; for example, advertising investments large firms have higher labor, total factor productivity, $\mathrm{CPH}$ and WPH in the Ecuadorian manufacturing industry compared to non-advertising investment firms. In this line, managers need to know the magnitude of the advertising premia on labor, capital, and TFP, since productivity may be related to economic firm growth.

Table 1 also shows the difference between advertising investment firms and non-advertising firms in terms of large and MSME firms. Again, in mean, advertising investments, large firms, and MSME have larger economic and productivity performance than their counterparts. For example, advertising investments large firms have 1.7 times more gross revenue, employment, capital stock, and raw materials than their counterparts. This suggests that investments in advertising also require more employment, assets, and raw materials to increase production. A similar pattern is showing on MSME firms.

\footnotetext{
${ }^{2}$ sheets and financial statements year after year until the month of April of the following year, those companies that for two consecutive years do not deliver their balance sheets and financial statements to the SCVS are sent to a declaration process of inactivity to then go to a dissolution process.

${ }^{3}$ The Gross Revenue and Raw Materials are deflated using industry-specific price index obtained from the Ecuadorian National Institute of Statistics.

${ }^{4}$ Firm size is defined in the Organic Code of Production, Trade and Investment of Ecuador: Microenterprises: Between 1 to 9 workers or revenue less than $\$ 100,000.0$. Small firms: Between 10 to 49 workers or revenue between \$100,001.0 and \$1,000,000.0. Medium firms: Between 50 to 199 workers or revenue between \$1,000,001.0 and \$ 5,000.000.0. Large firms: More than 200 workers or revenue above $\$ 5,000,001.0$. Always prevailing revenue over the number of workers.
} 
In Annexes, Table 2A, we show the evolution of the number of firms that invest in the advertisement, by two-digit ISIC, in percentages for the Ecuadorian manufacturing industry for the period 2007-2017. In Table 3A, we present the total number of firms by year and two-digit ISIC including Advertising Investments and non-advertising investment Firms. We also show that the number of firm's investments in advertising is not constant over the years by the manufacturing sector; nevertheless, Table $4 \mathrm{~A}$ shows that more than $50 \%$ of all manufacturing firms invest in advertising in each year. Finally, Table $5 \mathrm{~A}$ shows the firm's distribution by region; the Costa and Sierra regions are the more representatives, with 42 and 57 percent of firms respectively. The rest of 1 percent is in Oriente and Insular region.

Table 1. Variables definition and mean characteristics for Advertisers and Non-advertisers.

(Advertisers are defined as continuing and entering advertisers over the whole period)

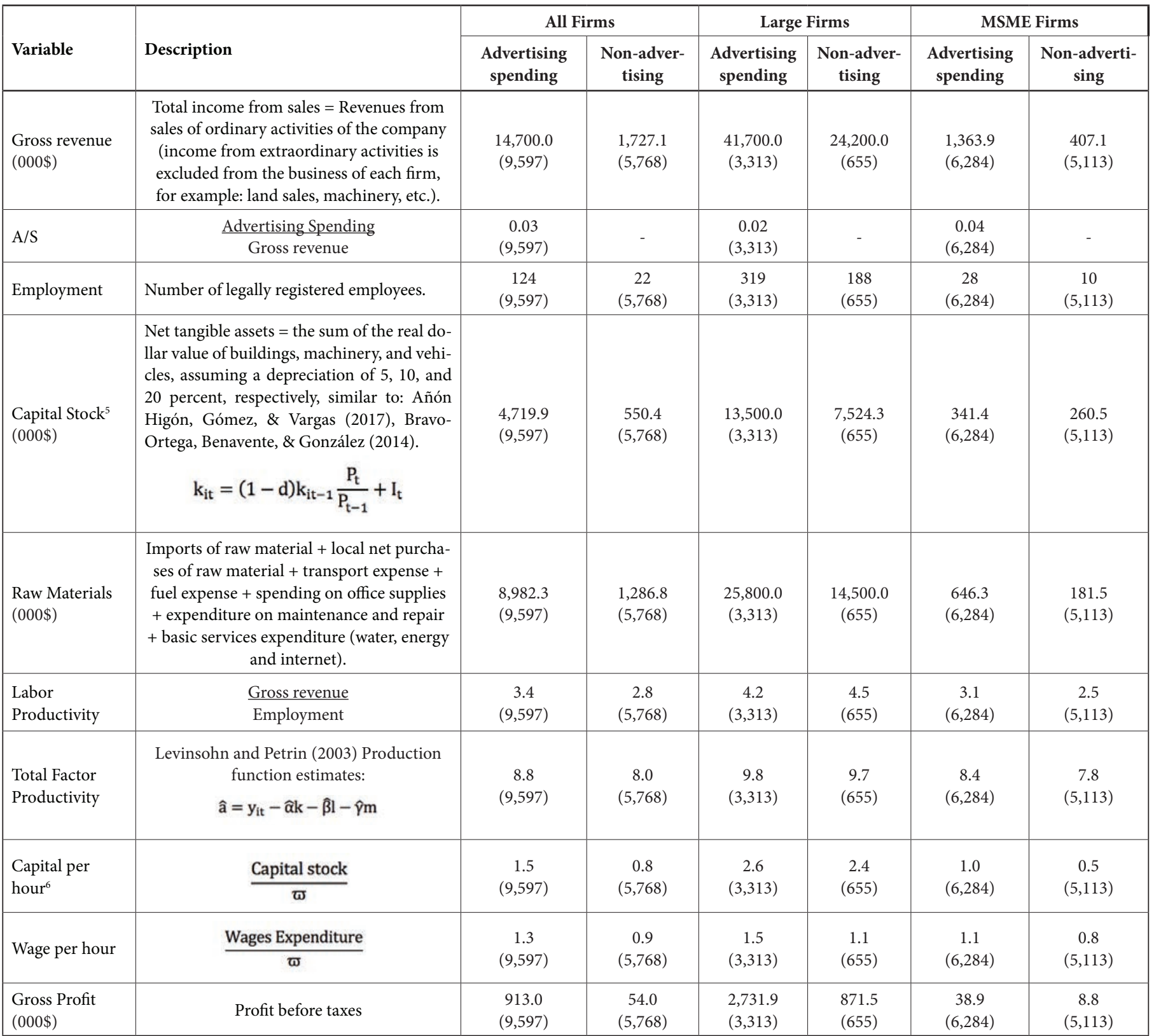

Notes: Values in brackets are the number of observations per subsample.

${ }^{5}$ We measure the Capital stock with the Gross Investment in equipment in year $\mathrm{t}\left(I_{\mathrm{iti}}\right)$, net fixed assets in real value (physical capital in year $\left.\left.t-1\right)\left(k_{i t-1}\right)\right)$, a depreciation rate $\left(d_{-} i t\right)$ and the price index for equipment at the industry level $\left(P_{t}\right)$ obtained from the Ecuadorian National Institute of Statistics. This measure is also used in Camino (2017), Fariñas, López, \& Martín-Marcos (2014), López (2014), Echavarría, Arbeláez, \& Rosales (2006). Similar to Añón Higón, Gómez, \& Vargas (2017) I estimate the stock of physical capital, with the initial stock $\left(\mathrm{k}_{0}\right): \mathrm{k}_{0}=(1-d)^{\mathrm{VM}} T F A_{0} \frac{P^{0}}{P_{0-V M}}$, where TFA is the value of total fixed assets, VM is the average age of a firm's fixed assets.

${ }^{6} \varpi$ is the annual effective worked hours. I pondered a mean of 2086 hours worked per employee. 
In Figure 1, we show the mean of advertising investments intensity by year, in 2008 firms invested a little more than 5\% in advertising as a ratio of gross revenue, likewise 2016 are the only year in which firms in the manufacturing industry invested, on average, more than $4 \%$ of their gross revenue in advertising, the other years this ratio is less than $2 \%$. This evidence is in concordance with Srinivasan, Lilien, \& Sridhar (2011) that found that the impact on profits and stock returns of advertising spending during a recession depends on the market share, financial leverage, and product-market profile; however, firms tend to spend more in advertising in recession periods. In Ecuador, 2008 and 2015 - 2016 are considered recession years since the Gross Domestic Product got negative growth rates.

Additionally, in Figure 1, we show the firm intensity of the average investment in advertising for the 24 manufacturing sub-sectors according to the ISIC classification. The subsector that invests most in advertising, as the ratio of gross revenue, is the manufacture of chemicals and chemical products with an intensity of $5 \%$, followed by the manufacture of food products with an average of $4 \%$, and the third subsector that most invests in advertising is the manufacture of basic pharmaceutical products and pharmaceutical preparations with around $3 \%$ on average during the 11 years of analysis. The evidence is similar to Sun (2014) who found that good consumer industries are more intensity advertising than industrial goods industries on average.

Coello-Montecel (2017) and Solano-Solano, Camino-Mogro, \& Alvarado (2017) found that ISIC 10 and 21, manufacturing subsectors are non-concentrated, but ISIC 26 is highly concentrated in Ecuador during 2013 - 2015; in this line, it is expected that a competitive market invest in advertising to achieve an improvement over competitors and to differentiate themselves from the other firms but in highly concentrated markets advertising spending in many cases may be unnecessary (Comanor \& Wilson, 1974; Sutton, 1991; Askenazy, Breda, \& Irac, 2016).

Figure 1. Mean of advertising spending intensity
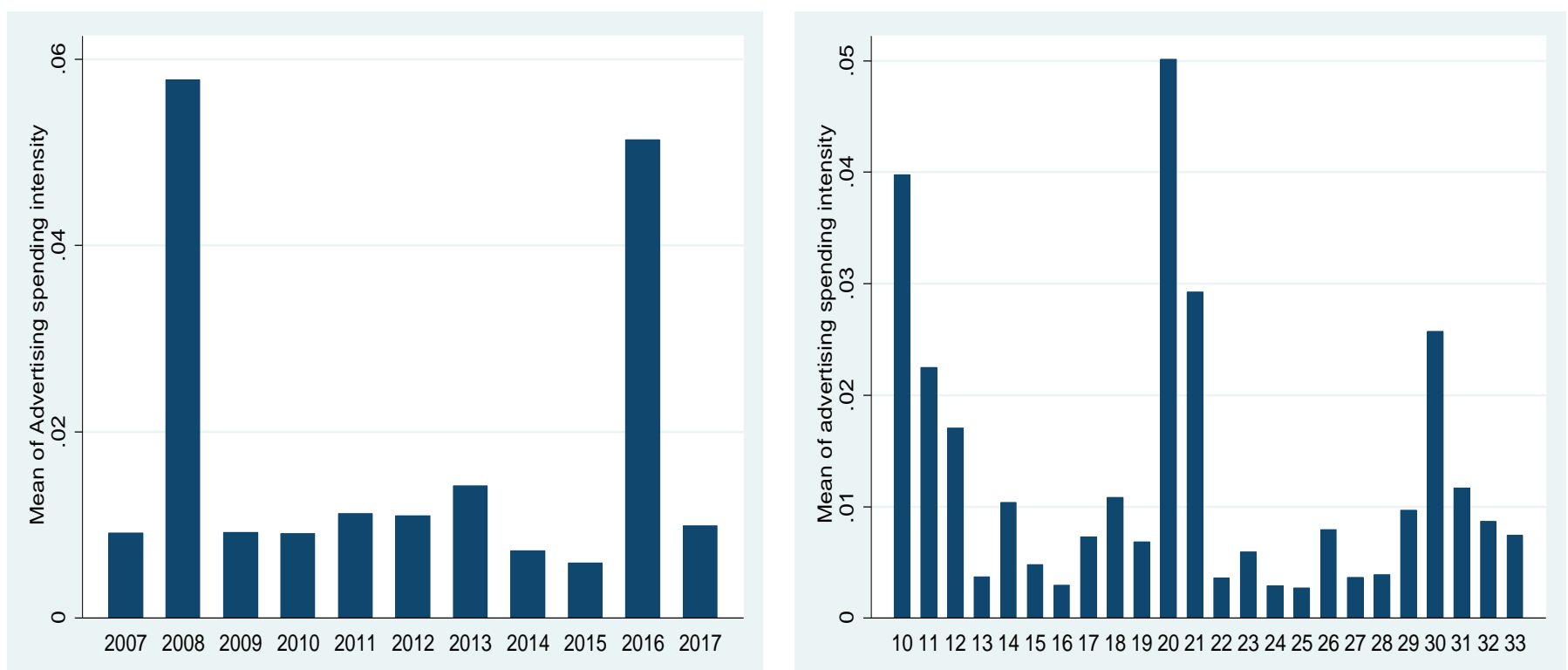

Source: Superintendencia de Compañías, Valores y Seguros

Elaboration: The author

\subsection{Econometric Strategy}

This study considers a three-stage estimation strategy. First, we determine if firms that invest in advertising have a better economic performance and productivity than those firms that do not invest in advertising, for this we use a simple framework where the average difference between advertising investments firms and non-advertising investments firms are calculated after controlling by size, FDI, industry, time and region. The specification allows capturing the relationship between investments in advertising and a set of firm characteristics; the Advertising Premia is estimated from the following equation:

$$
\begin{aligned}
& \ln _{i t}=\alpha+\text { Advertising }_{i t}+\lambda \text { Size }_{i t}+\theta F D I_{i t}+\sum_{I} \delta_{I} \text { Industry }_{i}+\sum_{T} \delta_{T} \text { Time }_{t} \\
& +\sum_{R} \delta_{R} \text { Region }_{r}+\varepsilon_{i t}
\end{aligned}
$$


Where $\Psi_{\text {it }}$ is a vector of economic and productivity characteristics ${ }^{7}$ of firm $i$ at time $t$; Advertising it $_{\text {in }}$ is dummy variable that indicates the investment on the advertising of each firm $i$ at time $t$; Size $_{i t}$ is a dummy variable that indicates the firm size ( 1 if the firm is large and 0 otherwise) of each firm $i$ at time $t ; F_{i t}$ is a dummy variable that indicates if firm i receives foreign direct investment on year $\mathrm{t}$; Industry $\mathrm{y}_{\mathrm{i}}$ is a set of 24 two-digit ISIC manufacturing industry dummies to control intra-sectorial heterogeneity; Time $_{t}$ is a set of 11-year dummies from 2007 to 2017 to control macroeconomic shocks; Region ${ }_{r}$ is a set of 4 region dummies to control geographic firm location; and $\varepsilon_{\mathrm{it}}$ is an error term. The coefficient is the
Advertising Premia $^{8}$ that firms get on each variable of economic and productivity performance when firm invests in advertising, a positive and significant coefficient represents the Advertising Premia, while a negative and significant coefficient shows a penalty for investments in advertising.

In the second stage, this paper estimates the Advertising Premia with a Cobb Douglas production function with the traditional inputs: capital, labor, and raw materials. The following equation denotes the specification using industry, time, region and two investments in advertising strategies that are invariant on time:

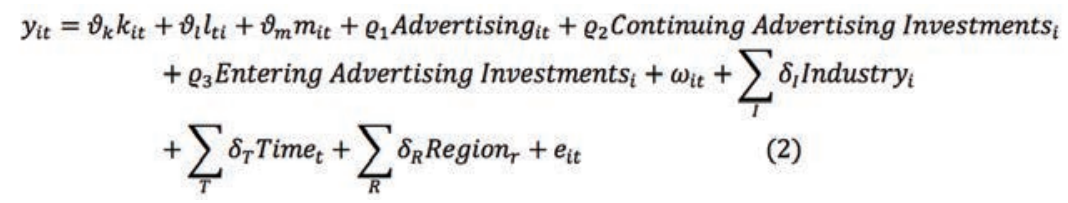

Where $y_{\mathrm{it}}$ is the log of the gross revenue of firm $i$ in year $\mathrm{t}, k_{i t}$ is the $\log$ of capital stock, $l_{i t}$ is the log of labor input and $m_{i t}$ describes the log of raw materials; $\omega_{i t}$ is the firm's productivity, which includes a mean level of firm efficiency and the deviation of that mean of each firm, in other words, $\omega_{i t}$ is assumed to be observable by the firm but not by the analyst (Van Beveren, 2012; Van Biesebroeck, 2007; Camino, 2017; Añón Higón, Gómez, \& Vargas, 2017; Syverson, 2011). Finally, $e_{i t}$ is an error term; Continuing Advertising Investments is a dummy variable that takes the value of 1 if Firms investing in advertising the whole period; and Entering Advertising Investments ${ }_{\mathrm{i}}$ is a dummy variable that takes the value of 1 if firm's entry to invest in advertising during the period without further changes. Since the estimation of a production, the function has been widely debated and has changed over time, from parametric to semi-parametric estimations, we use equation (2) to compare some parametric and semi-parametric methodologies.

In this line, authors like Van Biesebroeck (2007), Van Beveren (2012) and more recently, Bournakis \& Mallick (2018) show a survey of differences in each production function estimation methodology. For example, Van Biesebroeck (2007) mentions that the estimation of production functions can be done by parametric or semiparametric methods. Among the parametric methods, we have Ordinary Least Square (OLS); however, it is known that this method has several problems in its estimation. First, the estimated coefficients of the variable inputs will be biased upwards (endogeneity of the inputs). Second, the coefficient of capital will be biased downward (endogeneity of attrition) (Olley \& Pakes, 1996). Third, results biased due to a possible difference in the production technologies used by firms (De loecker, 2011). Another parametric method is Fixed Effects and Random Effects, both methods also have some limitations, the fixed effects estimator supposes that the productivity not observed in the production function is constant for each firm, Blundell \& Bond (2000) mention that productivity can be decomposed into a fixed effect and an autoregressive component AR (1), in such a way that the assumption of invariability of unobservable heterogeneity is relaxed. Finally, the random effects estimator assumes that the unobservable effect does not correlate with any explanatory variable.

In the same line, Van Beveren (2012) reviewed several production function estimates and compared the two semi-parametric estimations: Olley \& Pakes (1996) (OP) and Levinsohn \& Petrin (2003) (LP) arguing that both estimations solve the problem of simultaneity and reduce the endogeneity that parametric models can not solve. Nevertheless, the OP estimation only includes firms with positive investments that implies a loss of efficiency and can affect the collinearity between capital and investments (Ackerberg, Caves, \& Frazer, 2015).

The prevalence of zero investment observations in many data sets weakens the mapping, prompting Levinsohn \& Petrin (2003) to explore an alternative proxy for productivity (material input). In this sense, Van Beveren (2012) argues that if firms report zero investment in a significant number of cases, this casts doubt on the validity of the monotonicity condition; in this vein, Levinsohn \& Petrin (2003) use intermediate inputs to proxy for unobserved productivity, rather than investment; this implies that intermediate inputs (raw materials in this case) are expressed as a function of capital and productivity; and the Levinsohn-Petrin (LP) estimator do not incorporate the survival probability and correct for the selection bias. In addition, Van Beveren (2012) mentions that in light of the traditionally poor performance of both the GMM and fixed effects estimators, it would seem that the semi-parametric estimators are to be preferred. Nevertheless, comparing OP between LP estimators, the LP estimator has some advantages from the OP estimator, since this methodology maintains all the observations analyzed and the researcher can retain the full sample of firms in the first stage.

Finally, in the third stage, this paper calculates the TFP at firm-level using the LP estimator. We obtain $\widehat{\omega}_{i t}$ from the estimated production function. For this, we use the estimated coefficients of each of the inputs, which are, according to the literature on production functions, the most efficient. Thus, we get:

\footnotetext{
${ }^{7}$ In this study, those interest variables are the ones defined in Table 1, for the exception of $(\mathrm{A} / \mathrm{S})$.

${ }^{8}$ As the $\log$ approximation underestimates the difference for $\mathrm{e}$. To calculate the approximation of the $\Psi_{\mathrm{it}}$ increase when firm invest in advertising it has been done with the following expression: $\% \Delta \hat{\varrho}_{i t}=100\left[\exp \left(\hat{\varrho}_{\text {advertising }}\right)-1\right]$, see: Wooldridge $(2015)$ for details.
} 


$$
\widehat{\omega}_{i t}=y_{i t}-\widehat{\vartheta_{k}} k_{i t}-\widehat{\vartheta}_{l} l_{i t}-\widehat{\vartheta_{m}} m_{i t}
$$

Once the TFP at the firm level is calculated with equation (3), we measure the differences in $\operatorname{TFP}\left(\widehat{\omega}_{i t}\right)$ between advertising investment firms and non-advertising investment firms. We also divided the variable Advertising Strategy ${ }_{i}^{9}$ in a vector of advertising investment strategies that we explain in the Data Structure section. In this line, with the specification in equation (4) we explore how the different strategies in advertising show patterns in their productivity performance; furthermore, this new specification allows us to test the selection and learning hypothesis.

$$
\widehat{\omega}_{i t}=\alpha_{0}+\text { eAdvertising Strategy }_{i}+\sum_{\mathrm{t}=1}^{\mathrm{t}} \delta_{\mathrm{it}} \text { Control Variables }_{\mathrm{it}}+\varepsilon_{i t}
$$

The selection and learning hypothesis has been tested in the majority in international trade (exports and imports) and investments in Research and Development (R\&D). This new specification allows testing if more productivity firms select to invest in advertising (selection) and also to test if once firms invest in advertising. After that, they become more productivity (learning). Finally, to correctly test the learning hypothesis we modified equation (4) using as dependent variable the TFP growth $\left(\Delta \widehat{\omega}_{i t}\right)$ to get the relationship of entering to invest in advertising and growth of productivity, since investments on intangibles assets could generate later performance improvements as mention Hoberg \& Phillips (2016), Bontempi \& Mairesse (2015) Luo \& de Jong (2012), Hirschey (1982), (Weiss, 1969).

\section{Results}

In this section we show the results of Advertising Premia controlling simultaneously by region, 2 digits ISIC manufacturing industry and year. In addition, we estimate a parametric and semi-parametric Cobb Douglas production function using the Ordinary Least Square (OLS), Fixed Effects (FE), System Generalized Method of Moments (GMMSYS) proposed by Arellano \& Bond (1991), Blundell \& Bond (2000) and the preferred method, Levinsohn \& Petrin (2003) (LP) estimator, to obtain the TFP corrected for the simultaneous determination of inputs and productivity, also minimizing endogeneity problems and robust to the Ackerberg, Caves, \& Frazer (2015) critique. Finally, we employ a strategy analysis of investments in advertising over the entire period, in order to determine if those strategies increase the TFP, TFP growth, labor productivity, and gross revenue.
4.1. Economic performance differences between advertising investment firms and non-advertising investment firms.

As described above, the main objective of this paper is to get robust evidence that advertising investment ${ }^{10}$ firms have better economic and productivity performance than non-advertising investment firms. This procedure involves three steps. Table 2 reports the results from Fixed Effects (FE) regression from manufacturing sector described in equation (1), the results of Advertising Premia are obtained by

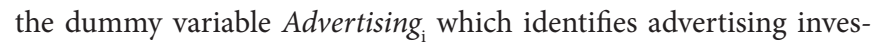
tment firms within the continuing and entering invest group. Controlling simultaneously by FDI, size, year, two-digit ISIS industry and region, the estimated coefficient $\mathrm{Q}$ is always positive and suggest that advertising investments are positively and significantly correlated with gross revenue, capital stock, labor, raw materials, gross profit, labor productivity, TFP, CPH and WPH.

This first result shows that there is an Advertising Premia in all the economic and productivity variables used on average; the largest difference is found in the economic performance measures. Advertising investment firms are almost 2 times the size of non-advertising investment firms in terms of gross revenue, capital stock, raw materials and gross profit, and 1 time major in employment. In terms of productivity, labor productivity and capital per hour $(\mathrm{CPH})$ are the largest difference between these two groups; we found that advertising investment firms have 38 and 31 percent larger labor productivity and $\mathrm{CPH}$ than their counterparts. In addition, total factor productivity (TFP) is 6 percent higher in advertising investment firms; this difference in productivity between advertising investment firms and non-advertising investment firms could be explained by better wages per hour (WPH), advertising investments firms pay $19 \%$ better wages than non-advertising investments firms. ${ }^{11}$

In general, firms that invest in advertising are substantially different from firms that not invest in advertising; in this sense, this evidence confirms there is an Advertising Premia in all the economic and productivity variables analyzed in this section. This evidence supports the OCDE's (2005) concept, which argues that a new marketing method involving significant changes in product design or packaging, product placement, product promotion or pricing, could increase innovation and also performance.

\footnotetext{
${ }^{9}$ This variable is constructed similar to Fariñas \& Martín-Marcos (2007) whose propose a decomposition of the export status. I modified that proposal to use the same definition with investments in advertising.

${ }^{10}$ Measured as marketing innovation similarly to OECD (2005) concept.

${ }^{11}$ As the log approximation underestimates the difference for $\mathrm{e}$. To calculate the approximation of the $\Psi_{\text {it }}$ increase when firm invest in advertising it has been done with the following expression: $\% \Delta \hat{\varrho}_{i t}=100\left[\exp \left(\varrho_{\text {advertising }}\right)-1\right]$, see: Wooldridge $(2015)$ for details.
} 
Table 2. The Premium to invest in advertising for various firm characteristics Advertisers are defined as Continuing and entering advertising investments firms

\begin{tabular}{|c|c|c|c|c|c|c|}
\hline \multirow{2}{*}{ Dependent variable } & \multirow{2}{*}{ Advertising Dummy } & \multicolumn{5}{|c|}{ Control Variables } \\
\hline & & Size & FDI & Region & Industry & Time \\
\hline Gross revenue & $\begin{array}{c}1.11^{* * *} \\
(0.05)\end{array}$ & $\begin{array}{c}1.34^{* * *} \\
(0.05)\end{array}$ & $\begin{array}{c}0.79^{* * *} \\
(0.08)\end{array}$ & Yes & Yes & Yes \\
\hline Capital stock & $\begin{array}{c}1.03^{* * *} \\
(0.07)\end{array}$ & $\begin{array}{c}1.16^{\star * *} \\
(0.06)\end{array}$ & $\begin{array}{c}1.05^{* * *} \\
(0.09)\end{array}$ & Yes & Yes & Yes \\
\hline Raw Materials & $\begin{array}{c}1.32^{* * *} \\
(0.07)\end{array}$ & $\begin{array}{c}1.71^{\star * *} \\
(0.07)\end{array}$ & $\begin{array}{c}0.69^{* * *} \\
(0.09)\end{array}$ & Yes & Yes & Yes \\
\hline Gross Profit & $\begin{array}{c}1.06^{* * *} \\
(0.06)\end{array}$ & $\begin{array}{c}1.84^{* * *} \\
(0.06)\end{array}$ & $\begin{array}{c}1.01^{\star * *} \\
(0.08)\end{array}$ & Yes & Yes & Yes \\
\hline Labor Productivity & $\begin{array}{c}0.32^{* * *} \\
(0.04)\end{array}$ & $\begin{array}{c}0.75^{* * *} \\
(0.04)\end{array}$ & $\begin{array}{c}0.29^{* * *} \\
(0.05)\end{array}$ & Yes & Yes & Yes \\
\hline Capital per hour & $\begin{array}{c}0.27^{* * *} \\
(0.05)\end{array}$ & $\begin{array}{c}0.40^{* * *} \\
(0.05)\end{array}$ & $\begin{array}{c}0.56^{\star * *} \\
(0.07)\end{array}$ & Yes & Yes & Yes \\
\hline Wage per hour & $\begin{array}{c}0.17^{* * *} \\
(0.02)\end{array}$ & $\begin{array}{c}0.26^{\star * *} \\
(0.03)\end{array}$ & $\begin{array}{c}0.20^{* * *} \\
(0.03)\end{array}$ & Yes & Yes & Yes \\
\hline
\end{tabular}

Notes: Estimates correspond to equation 1. Robust standard errors to heteroskedasticity of estimated coefficients in parentheses. ${ }^{* * *}$ indicates the significance at $1 \%$ confidence level, respectively. It includes 11-year dummies for the period $2007-2017$ and 24 industry dummies according to ISIC manufacturing codes. All dependent variables are in log. ${ }^{a}$ Total Factor productivity is estimated by the LP method.

4.2. Productivity differences between advertising investment firms and non-advertising investment firms with production functions.

The results obtained in the section above suggest an Advertising Premia in all the variables analyzed. In this path, this evidence allows us to continue with the second stage of the econometric strategy, given that in the third stage, we need the estimated coefficients of traditional inputs to get the TFP and get robust evidence between the relationship of investments in advertising strategies of firms.

In this second stage, this paper shows the results of some parametric and semi-parametric production function estimations; the preferred method is the LP estimator. Table 3 provides estimates of the production function of equation (2) using OLS, FE, GMM-SYS, and LP approach; all the methods have positive and significant inputs according to the empirical literature. However, the OLS has overestimated the inputs coefficients of labor and raw materials; surprisingly, the GMMSYS has underestimated all the effects of input variables. This suggests that those methods have not corrected the simultaneity in the decision of inputs usage and also endogeneity. In this line, we prefer the LP estimator because it includes a correction for the simultaneous of inputs and productivity (Petrin \& Levinsohn, 2012).

In Table 3, the results report that the major contributor of traditional inputs to gross revenue is raw materials, followed by labor input and the last is capital stock; this result is similar with other emerging economies like Colombia, Paraguay and Argentina (Hofman, Mas, Aravena, \& Fernández de Guevara, 2017; Aquino, 2015; Echavarría,
Arbeláez, \& Rosales, 2006). Furthermore, the Advertising it $_{\text {variable }}$ which is defined as dummy variable which takes the value of one if firm invests in advertising in year $t$ and 0 otherwise, is always positive and significant at 1 percent, this suggests that advertising investments firms, on average, have 22 percent higher productivity than those firms that not invest in advertising; this result is quite similar that the obtained in Table 2.

Also, we use two parametrizations of the firm-specific component $\varrho_{2}, \varrho_{3}$ which are continuing and entering advertising investments firms respectively; these variables were done in order to capture the advertising firm's strategy in year $t$, and to get more reliable results with invariant strategies in the whole period, in other words, these strategies allow us to endogenize the firm's decision to invest in advertising as business strategy.

The estimated coefficients of these two parametrizations are positive and significant at $1 \%$; showing that being a continuing investment advertising firm increase productivity in $13 \%$ than firms that not invest in advertising, also being entering investment advertising firm increase productivity in $22 \%$ on average. In this path, results in Table 3 confirm the Advertising Premia on firm productivity and gross revenue.

Finally, the $\mathrm{FDI}_{\mathrm{it}}$ shows that firms that receive FDI have higher gross revenue than firms who not receive FDI. This result is in concordance with the empirical literature. See for a detailed survey: (Agarwal, 1980; De Mello Jr, 1997; Saggi, 2002). In addition, Sun (2014) found 
that foreign entry is found to affect positively domestic firms' advertising intensity in the consumer goods industries and affect negatively advertising intensity in the industrial goods industries.

Overall, these results show similar relationships to those found in Table 2; although the effect of advertising investment is positive and significant on the level of output (gross revenue), this second stage only gives a big picture of how investments in advertising; nevertheless with output, because of this situation, The third stage will bring a more specific vision of how these investments can be more purely related to productivity and economic measures.

Table 3. Manufacturing Sector

Production Function: Alternative Estimators

\begin{tabular}{|c|c|c|c|c|}
\hline $\begin{array}{l}\text { Dependent } \\
\text { variable: } \mathrm{y}_{\mathrm{it}}\end{array}$ & $\begin{array}{l}\text { OLS } \\
(1)\end{array}$ & $\begin{array}{l}\mathrm{FE} \\
(2) \\
\end{array}$ & $\begin{array}{c}\text { GMM-SYS } \\
(3)\end{array}$ & $\begin{array}{l}\text { LP } \\
(4)\end{array}$ \\
\hline$k_{\mathrm{it}}$ & $\begin{array}{c}0.08^{* * *} \\
(0.01)\end{array}$ & $\begin{array}{c}0.08^{* * *} \\
(0.01)\end{array}$ & $\begin{array}{c}0.02^{* * *} \\
(0.01)\end{array}$ & $\begin{array}{c}0.05^{* * *} \\
(0.01)\end{array}$ \\
\hline$l_{\text {it }}$ & $\begin{array}{c}0.30^{* * *} \\
(0.01)\end{array}$ & $\begin{array}{c}0.21^{* * *} \\
(0.01)\end{array}$ & $\begin{array}{c}0.06^{* * *} \\
(0.01)\end{array}$ & $\begin{array}{c}0.26^{* * *} \\
(0.01)\end{array}$ \\
\hline$m_{\mathrm{it}}$ & $\begin{array}{c}0.46^{\star * *} \\
(0.02)\end{array}$ & $\begin{array}{c}0.35^{* * *} \\
(0.01)\end{array}$ & $\begin{array}{c}0.14^{* * *} \\
(0.01)\end{array}$ & $\begin{array}{c}0.31^{* * *} \\
(0.02)\end{array}$ \\
\hline Advertising $_{\text {it }}$ & $\begin{array}{c}0.18^{* * *} \\
(0.01)\end{array}$ & $\begin{array}{c}0.17^{* * *} \\
(0.01)\end{array}$ & $\begin{array}{c}0.06^{* * *} \\
(0.01)\end{array}$ & $\begin{array}{c}0.22^{* * *} \\
(0.02)\end{array}$ \\
\hline Continuing Advertising Investment $_{\mathrm{i}}$ & $\begin{array}{c}0.16^{* * *} \\
(0.02)\end{array}$ & $\begin{array}{c}0.44^{* * *} \\
(0.04)\end{array}$ & $\begin{array}{c}3.01 \\
(4.87)\end{array}$ & $\begin{array}{c}0.13^{* * *} \\
(0.03)\end{array}$ \\
\hline Entering Advertising Investments $s_{\mathrm{i}}$ & $\begin{array}{c}0.09^{* * *} \\
(0.05)\end{array}$ & $\begin{array}{c}0.18^{* * *} \\
(0.04)\end{array}$ & $\begin{array}{l}12.52 \\
(8.92)\end{array}$ & $\begin{array}{l}0.11^{* *} \\
(0.05)\end{array}$ \\
\hline Instruments & - & - & $\mathrm{t}-2$ and $\Delta(\mathrm{t}-2)$ & - \\
\hline Sargan (p-value) & - & - & 0.24 & - \\
\hline $\operatorname{AR}(1)$ (p-value) & - & - & 0.001 & - \\
\hline $\operatorname{AR}(2)$ (p-value) & - & - & 0.19 & - \\
\hline AR (3) (p-value) & - & - & 0.43 & - \\
\hline Year & Yes & Yes & Yes & Yes \\
\hline ISIC & Yes & Yes & Yes & Yes \\
\hline Region & Yes & Yes & Yes & Yes \\
\hline Observations & 31,064 & 31,064 & 18,425 & 31,064 \\
\hline
\end{tabular}

Notes: Estimates correspond to equation 3. Robust standard errors to heteroskedasticity of estimated coefficients in parentheses in columns (1) to (3). ${ }^{* * *}$, ** indicates the significance at 1\%,5\% confidence level respectively. It includes 11-year dummies for the period $2010-2017,24$ industry dummies according to ISIC codes and 4 region dummies. Advertising is defined as a dummy variable that takes the value of 1 if a firm invests in advertising in year $t$ and 0 otherwise. The GMM-SYS estimator uses the instruments: $y_{i t-1} \ldots y_{i t-3}, l_{i t-1} \ldots l_{i t-3}, m_{i t-1} \ldots m_{i t-3}$ and $k_{\mathrm{it}-1}$ (as predetermined) and also instruments as: $\left(\mathrm{y}_{\mathrm{it}-1}-\mathrm{y}_{\mathrm{it}-2}\right),\left(l_{\mathrm{it} t-1}-l_{\mathrm{it}-2}\right),\left(m_{\mathrm{it}-1}-m_{\mathrm{it}-2}\right)$. The Sargan test is the p-value of the over-identification restriction test of instruments. The AR (1), AR (2) and AR (3) represents the Arellano-Bond p-value, to test that the error of the estimation is not correlated serially with the inputs, in such a way that the null hypothesis is not autocorrelation in at least the second autoregressive process AR (2). The LP estimator is the stochastic process of $\omega_{\text {it }}$ specifies the third-order polynomials and Advertising it $_{\text {it }}$ threat as free variable, bootstrapped standard errors with 250 replications in parentheses are reported.

\subsection{Productivity and economic differences by advertising investment strategies.}

The third stage of the econometric strategy is to give robust evidence of the causal relationship between measures of productivity and gross revenue with the firm's advertising investment strategies. The classification about the different strategies that firms could do during the whole period of this analysis allows me to treat this causal mechanism linking advertising investment to productivity and also to test two hypothesis that literature has focused on international trade and R\&D like: self-selection and learning by "exporting or doing". Furthermore, differentiation in advertising investment strategies during a period of time allows us to prove more efficiently if advertising investments really improve productivity and economic performance as shown in the previous sections.

In this path, once the production function is estimated with an LP estimator, the TFP is calculated using equation (3). After that, we reparametrize the firm-specific component in equation (4) into a set of 
four dummies of advertising investment strategies, we improve the interpretation of the estimated coefficients to catch who is who in the market and what strategy is better for productivity performance. In addition, we use the similar approach of Fariñas \& Martín-Marcos (2007) to test the self-selection and learning by advertising hypothesis, since to prove those, the estimated coefficient of continuing and entering advertising investment needs to be higher than exiting advertising investment (selfselection hypothesis) and the coefficient of entering advertising investment needs to be positively and significantly related with TFP growth.

Using equation (4) and replacing the variable Advertising Status $_{\mathrm{i}}$ with a vector of advertising investment strategies dummies such as: continuing advertising investment firms, entering advertising investment firms, switching advertising investment firms, exiting advertising investment firms and non-advertising investment firms; we obtain the estimated coefficient e for each group by advertising investment status, and we compare the estimated coefficients of each group to test the self-selection and learning by advertising hypothesis. Table 4 reports the results of the estimation mentioned for the Ecuadorian manufacturing sector controlling by size, FDI, year, two-digit ISIC and region.

In Table 4, we found, on average, that productivity of continuing advertising investment firms is positive and higher than non-advertising investment firms being this difference statistically significant. In this line, firms that invest in advertising over all the period analyzed increase their productivity by $9 \%$ in the year invested compared to non-advertising firms. According to the self-selection hypothesis, we found that continuing advertising investment firms have higher productivity than exiting advertising investment firms; nevertheless, entering advertising investment firms have similar productivity with exiting advertising investment firms; this result is in favor of selection on the exit side of the market but not in the entry side, since the productivity of entering and exiting advertising investment firms are similar. This result is in line with the argue of Kor \& Mahoney (2005) whose mention that a firm's investments in advertising can help it to learn and absorb new knowledge more efficiently, to develop a distinctive innovative capability.

We also find that firms with an entering investment strategy increase their TFP growth in around 6\%, suggesting that this strategy not only increases the TFP in the same year but also increases productivity in future years. These results are in concordance with the argue of Narayanan, Desiraju, \& Chintagunta (2004), Kremer, Bijmolt, Leeflang, \& Wieringa (2008), Osinga, Leeflang, Srinivasan, \& Wieringa (2011) whose mention that advertising does not necessarily generate an expected sales return in the same time of the advertising investment, the impact of this investment needs time to change the perception of the consumers and set the differentiation from competitors. In addition, this positive and significant coefficient of entering advertising investment firms with TFP proves the learning by advertising hypothesis. This suggests that start to invest in advertising may improve productivity through this investment.

On the other hand, switching advertising investment firms show a higher TFP (6\%) compared to non-advertising investment firms. Finally, we obtain that the average productivity of exiting advertising investment firms is also $6 \%$ higher than non-advertising investment firms. It is important to mention that results find a positive relationship and important impacts on TFP level across the different strategies of advertising; previous research has also indicated that strategic entrepreneurship investments, such as those in R\&D and advertising and others, positively affect TFP (Urata \& Kawai, 2002; Balasubramanian \& Lieberman, 2010; Cucculelli \& Bettinelli, 2015).

Table 4. Manufacturing Sector

Economic and Productivity performance by advertising investment strategy

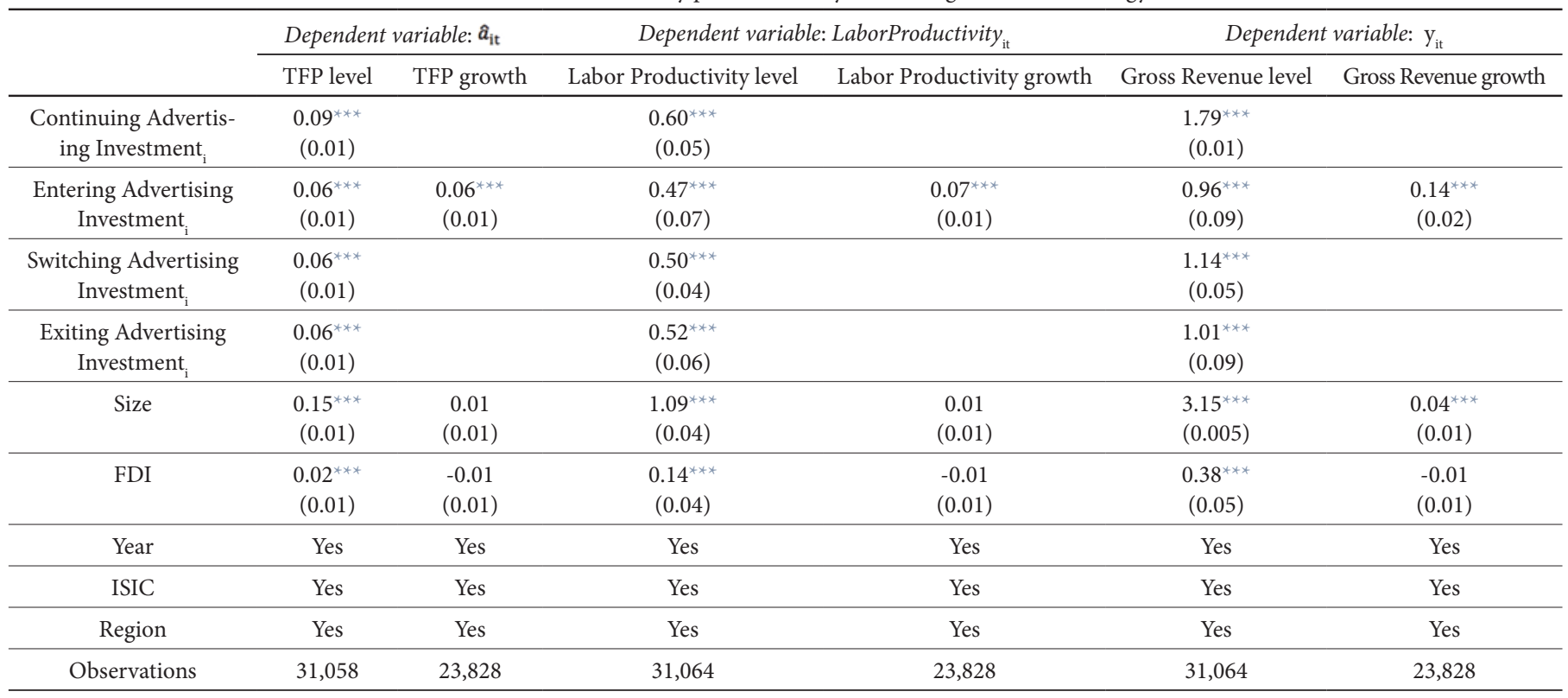

Notes: Estimates correspond to equation 6 . Robust standard errors to heteroskedasticity of estimated coefficients in parentheses. ${ }^{* * *}$ indicates the significance at $1 \%$ confidence level. Advertising status is decomposed into four dummies: continuing, entering, switching, and exiting advertising being the reference category nonadvertising spending firms. We apply a set 24 industry, 11 time and 4 region dummies. TFP, Labor Productivity, and Gross Revenue levels are in logs. 
In terms of labor productivity, Table 4 shows similar but higher estimated coefficients on each advertising investment strategies. Also, the self-selection on the exit side of the market is confirmed but not on the entry side of the market. According to the learning by advertising hypothesis, we confirm that entering advertising investment firms have higher labor productivity growth than non-advertising investment firms, suggesting that there is a learning process that enables the improvement of productivity.

Finally, we found that advertising investment strategies have a higher pattern on the causal relationship with gross revenue. The results of each strategy are significantly higher comparing with the other measures of productivity; nevertheless, this pattern is the expected, since the supporting evidence of advertising accountability and the processes would make advertising spending more "essential to firm organic growth" (Gupta \& Steenburgh, 2008), and the benefits induced by advertising, in turn, boost future sales and profits of the firm (Chen \& Waters, 2017; Osinga, Leeflang, Srinivasan, \& Wieringa, 2011).

These advertising investment strategies throughout the analyzed period show us the impact of each strategy on productivity and gross revenue, mainly showing us that investing is not the same as investing at random or spending a year or several to obtain an improvement in the productivity and also in the productivity growth. Advertising investment allows firms to improve their productivity and gross revenue growth rates, which in the medium and long run will lead them to obtain better economic performance.
4.4. Robustness Check: the lag effect of advertising investments on economic performance

Authors like Narayanan, Desiraju, \& Chintagunta (2004), Kremer, Bijmolt, Leeflang, \& Wieringa (2008), Osinga, Leeflang, Srinivasan, \& Wieringa (2011) and others, argues that investments in advertising could have a lag effect on economic performance, specifically on sales and productivity, and this effect often becomes observable only after some time. In this line, we employ a robustness check in Table 5 using the same measures of productivity and gross revenue as dependent variables and the Advertising Investment $_{\mathrm{it}-\mathrm{n}}$ as independent variable, controlling by size, FDI, industry, year and region.

The Advertising Investment ${ }_{\mathrm{it}-\mathrm{n}}$ capture the effect of lag 1 and lag 2 on TFP, labor productivity, gross revenue, and growth rates. The results in Table 5 are quite similar to those obtained in Tables 3 and 4; the effect of the second lag of advertising investment is always lower than the effect of the first lag on productivity and sales measure. This evidence is in favor of the authors mention above and also suggests that the effect with time decreases; other authors suggest that the absortive capacity is always delayed because firms need to adjust their knowledge. Another important aspect of this result is that a new marketing method involving significant changes in product promotion or pricing needs to be improved and changed over time because the consumers ask for constant changes to meet their needs, this result is consistent with the concept of marketing innovation proposed by OCDE (2005).

Table 5. Manufacturing Sector

Economic and Productivity performance by advertising spending strategy

\begin{tabular}{|c|c|c|c|c|c|c|c|c|c|c|c|c|}
\hline & \multicolumn{4}{|c|}{ Dependent variable: $\hat{a}_{\mathrm{it}}$} & \multicolumn{4}{|c|}{ Dependent variable: LaborProductivity ${ }_{\mathrm{it}}$} & \multicolumn{4}{|c|}{ Dependent variable: $\mathrm{y}_{\mathrm{it}}$} \\
\hline $\begin{array}{l}\text { Advertising } \\
\text { Investment }_{\text {it-n }}\end{array}$ & $\begin{array}{c}0.04^{* * *} \\
(0.01) \\
\end{array}$ & $\begin{array}{l}-0.01 \\
(0.01) \\
\end{array}$ & $\begin{array}{c}0.03^{* * *} \\
(0.01) \\
\end{array}$ & $\begin{array}{l}-0.01 \\
(0.01) \\
\end{array}$ & $\begin{array}{c}0.24^{* * *} \\
(0.02) \\
\end{array}$ & $\begin{array}{l}-0.02 \\
(0.02) \\
\end{array}$ & $\begin{array}{c}0.23^{* * *} \\
(0.03) \\
\end{array}$ & $\begin{array}{c}0.02 \\
(0.02) \\
\end{array}$ & $\begin{array}{c}0.84^{* * *} \\
(0.03) \\
\end{array}$ & $\begin{array}{c}-0.05^{* * *} \\
(0.01)\end{array}$ & $\begin{array}{c}0.76^{* * *} \\
(0.03) \\
\end{array}$ & $\begin{array}{c}-0.02^{* * *} \\
(0.01)\end{array}$ \\
\hline FDI & $\begin{array}{c}0.02^{* * *} \\
(0.01)\end{array}$ & $\begin{array}{l}-0.01 \\
(0.01)\end{array}$ & $\begin{array}{l}0.02^{* * *} \\
(0.01)\end{array}$ & $\begin{array}{l}-0.02 \\
(0.02)\end{array}$ & $\begin{array}{c}0.14^{* * *} \\
(0.05)\end{array}$ & $\begin{array}{c}0.01 \\
(0.01)\end{array}$ & $\begin{array}{c}0.13^{* * *} \\
(0.05)\end{array}$ & $\begin{array}{l}-0.02 \\
(0.02)\end{array}$ & $\begin{array}{c}0.40^{* * *} \\
(0.05)\end{array}$ & $\begin{array}{l}-0.02 \\
(0.02)\end{array}$ & $\begin{array}{l}0.40^{* * *} \\
(0.05)\end{array}$ & $\begin{array}{l}-0.02 \\
(0.02)\end{array}$ \\
\hline Year & Yes & Yes & Yes & Yes & Yes & Yes & Yes & Yes & Yes & Yes & Yes & Yes \\
\hline
\end{tabular}

Notes: Estimates correspond to equation 6. Robust standard errors to heteroskedasticity of estimated coefficients in parentheses. ${ }^{* * *}$ indicates the significance at $1 \%$ confidence level. Advertising Spending is a dummy variable being 1 if firm $i$ invest in advertising on year $\mathrm{t}$, being the reference category non-advertising spending firms. We apply a set 24 industry, 11 time, and 4 region dummies. TFP, Labor Productivity, and Gross Revenue levels are in logs. Columns (3), (4), (7), (8), (11) and (12) the t-n represents the second lag of advertising spending status firm. 
Table 5 shows that firms that invest in advertising a previous year have a higher TFP, specifically on $4 \%$, the labor productivity on $24 \%$, and gross revenue on $84 \%$ compared with firms that not invest in advertising. Additionally, firms that invest in advertising two delayed years have a higher TFP, specifically on $3 \%$, the labor productivity on $23 \%$, and gross revenue on $76 \%$ compared with firms that not invest in advertising. These results show that there is a persistent effect on this economic and productivity performance. However, it is always smaller than the effect in the same year, as is showed in Table 4.

\section{Final Remarks}

We use a microeconomic dataset from the supervisory institution SCVS to explore the differences between economic and productivity performance between advertising investment firms and non-advertising investment firms in the Ecuadorian manufacturing sector during the period 2007 - 2017. This paper applies three different approaches to get robust evidence about the differences between those groups of firms. First, we obtain the Advertising Premia for all the outcomes variables using a regression that allows controlling for size, FDI, region, industry, and year. Second, we estimate the TFP using several production functions approach. We prefer the LP estimator that controls the unobserved heterogeneity and simultaneous inputs decision problems. Finally, using the TFP of LP estimator, we measure the differences in TFP between advertising investment firms and nonadvertising investment firms. Furthermore, we divide the advertising investments into many strategies that firms could apply to increase not only TFP, also gross revenue.

The results indicate that manufacturing firms that invest in advertising (continuing and entering advertising investment) have an $\mathrm{Ad}$ vertising Premia on economic and productivity variables; particularly, Advertising Premia is higher on economic outcomes. In this sense, results suggest that investments in advertising increase productivity and economic performance. Additionally, the differences in productivity between advertising investment firms and non-advertising investment firms in the manufacturing sector are around $22 \%$ permanently higher TFP.

Likewise, this research finds systematic patterns in the relationship between performance at the firm level and transitions between the invest in advertising and non-investment in advertising. In particular, this paper finds that continuing, entering, switching and exiting advertising investments firms have greater TFP than non-advertising investments firms; this paper also finds that continuing advertising investment strategy firms have higher TFP, labor productivity and gross revenue than exiting advertising investment firms, suggesting a self-selection in the exit side of the market but not in the entry side of the market, because entering advertising investment strategy firms have the same TFP, and lower labor productivity and gross revenue than exiting counterparts.

Form the side of the learning hypothesis. This study finds that after firms entering to invest in advertising, firms experience an improvement in TFP, labor productivity, and gross revenue growth, which are in favor of learning by advertising hypothesis. This evidence is clearer when we test the argument that investments in advertising could have a lag effect on economic performance, specifically on sales and productivity. These results go in line with the hypothesis suggested by other authors that mention the impact of advertising in revenue is not immediately, is an investment that obtains their premias years after the investment.

Finally, these findings have some policy implications in terms of industrial policy. First, although the intensity of advertising investment is low, those intensive firms have a higher productivity than those that do not spend in this area, this implies that if a certain amount of advertising investment is implemented, it could be considered as innovation in product or market, since the success of a new product or process on the market may depend on the quality of advertising (Mohnen \& Hall, 2013) and that this investment has fiscal incentives, it may also help to improve firms innovation given its effect on product differentiation which might, in turn, improve business sales and job creation. Second, improving the quality of products is also advertising investment, many actions that may help firms to differentiate themselves from competitors and also increase TFP and gross revenue.

Even though this paper analysis the relationship of investment in advertising and various measures of productivity and economic performance in the Ecuadorian manufacturing sector, the present study has some limitations. First, those derived from the nature of the data source used since firms may not report certain investments or place them in other types of accounts. Second, this study focuses only in advertising investments; however, there is a growing current that studies complementarities, see for example Añón Higón, Gómez, \& Vargas (2017), Ennen \& Richter (2010). In addition, our dataset does not allow us to study complementarities since no information about $R \& D$, human capital, patents organizational innovation is given. Finally, these results should be interpreted with caution because not major evidence in other Latin American countries is known; this is why this evidence aims to open the debate in similar Ecuadorian economies.

\section{References}

Aaker, D., \& Myers, J. (1987). Advertising management. Englewood Cliffs: Prentice-Hall.

Ackerberg, D., Caves, K., \& Frazer, G. (2015). Identification properties of recent production function estimators. Econometrica, 83(6), 2411-2451. doi:10.3982/ECTA13408

Agarwal, J. (1980). Determinants of foreign direct investment: A survey. Weltwirtschaftliches Archiv, 116(4), 739-773. doi: 10.1007/ BF02696547

Ali Shah, S., \& Akbar, S. (2008). Value relevance of advertising expenditure: A review of the literature. International Journal of Management Reviews, 10(4), 301-325. doi:10.1111/j.1468-2370.2007.00228.x 
Añón Higón, D., Gómez, J., \& Vargas, P. (2017). Complementarities in innovation strategy: do intangibles play a role in enhancing firm performance? Industrial and Corporate Change, 26(5), 865-886. doi:10.1093/icc/dtw055

Aquino, J. (2015). Estimación de la Productividad Total de Factores de Paraguay: mediciones alternativas. Ministerio de Hacienda, Dirección de Estudios Económicos. Asunción: Ministerio de Hacienda.

Arellano, M., \& Bond, S. (1991). Some tests of specification for panel data: Monte Carlo evidence and an application to employment equations. The review of economic studies, 58(2), 277-297. doi: $10.2307 / 2297968$

Askenazy, P., Breda, T., \& Irac, D. (2016). Advertising and R\&D: theory and evidence from France. Economics of Innovation and New Technology, 25(1), 33-56. doi:10.1080/10438599.2015.1046670

Assaf, A., Josiassen, A., Mattila, A., \& Cvelbar, L. (2015). Does advertising spending improve sales performance? International Journal of Hospitality Management, 48, 161-166. doi:10.1016/j.ijhm.2015.04.014

Balasubramanian, N., \& Lieberman, M. (2010). Industry learning environments and the heterogeneity of firm performance. Strategic Management Journal, 31(4), 390-412. doi:10.1002/smj.816

Baye, M., Jansen, D., \& Lee, J.-W. (1992). Advertising effects in complete demand systems. Applied Economics, 24(10), 1087-1096. doi: 10.1080/00036849200000001

Blundell, R., \& Bond, S. (2000). GMM estimation with persistent panel data: an application to production functions. Econometric Reviews, 19(3), 321-340. doi:10.1080/07474930008800475

Bontempi, M., \& Mairesse, J. (2015). Intangible capital and productivity at the firm level: a panel data assessment. Economics of Innovation and New Technology, 24(1-2), 22-51. doi:10.1080/10438599.2014.897859

Bournakis, I., \& Mallick, S. (2018). TFP estimation at firm level: The fiscal aspect of productivity convergence in the UK. Economic Modelling, 70, 579-590. doi:10.1016/j.econmod.2017.11.021

Bravo-Ortega, C., Benavente, J., \& González, Á. (2014). Innovation, exports, and productivity: Learning and self-selection in Chile. Emerging Markets Finance and Trade, 50(sup1), 68-95. doi:10.2753/ REE1540-496X5001S105

Camino, S. (2017). Estimación de una función de producción y análisis de la productividad: El sector de innovación global en mercados locales. Estudios Gerenciales, 33(145), 400-411. doi:10.1016/j. estger.2017.10.004

Camino-Mogro, S., Armijos-Bravo, G., \& Cornejo-Marcos, G. (2018). Productividad Total de los Factores en el sector manufacturero ecuatoriano: evidencia a nivel de empresa. Cuadernos de Economía, 41(117), 241-261. doi:10.32826/cude.v41i117.91
Chauvin, K., \& Hirschey, M. (1993). Advertising, R\&D expenditures and the market value of the firm. Financial management, 22(4), 128140. doi: $10.2307 / 3665583$

Chen, J., \& Waters, G. (2017). Firm efficiency, advertising and profitability: Theory and evidence. The Quarterly Review of Economics and Finance, 63(1), 240-248. doi:10.1016/j.qref.2016.04.004

Coello-Montecel, D. (2017). ¿Poder de Mercado o Eficiencia?: Determinantes de la Rentabilidad del Sector Manufacturero Ecuatoriano Durante el Período Post Dolarización. X-pedientes Económicos, 1(1), 56-77.

Comanor, W., \& Wilson, T. (1974). Advertising and market power. Cambridge,MA: Harvard University Press.

Connolly, R., \& Hirschey, M. (1984). R \& D, Market Structure and Profits: A Value-Based Approach. The Review of Economics and Statistics, 66(4), 682-686. doi:10.2307/1935995

Corchón, L., \& Marini, M. (2018). Handbook of Game Theory and Industrial Organization (Vol. 2). (L. Corchón, \& M. Marini, Eds.) Massachusetts, EEUU: Edward Elgar Publishing.

Corrado, C., Hulten, C., \& Sichel, D. (2005). Measuring Capital and Technology: An Expanded Framework. In Measuring capital in the new economy (pp. 11-46). Chicago, EEUU: University of Chicago Press.

Corrado, C., Hulten, C., \& Sichel, D. (2009). Intangible capital and US economic growth. Review of income and wealth, 55(3), 661-685. doi:10.1111/j.1475-4991.2009.00343.x

Crass, D., \& Peters, B. (2014). Intangible assets and firm-level productivity. ZEW-Centre for European Economic Research Discussion Paper, 14-120. doi:10.2139/ssrn.2562302

Crass, D., Licht, G., \& Peters, B. (2015). Intangible assets and investments at the sector level: Empirical evidence for Germany. In Intangibles, Market Failure and Innovation Performance (pp. 57-111). Springer, Cham.

Cucculelli, M., \& Bettinelli, C. (2015). Business models, intangibles and firm performance: evidence on corporate entrepreneurship from Italian manufacturing SMEs. Small Business Economics, 45(2), 329350. doi:10.1007/s11187-015-9631-7

De loecker, J. (2011). Product differentiation, multiproduct firms, and estimating the impact of trade liberalization on productivity. Econometrica, 79(5), 1407-1451. doi:10.3982/ECTA7617

De Mello Jr, L. (1997). Foreign direct investment in developing countries and growth: A selective survey. The Journal of Development Studies, 34(1), 1-34. doi:10.1080/00220389708422501

Dorfman, R., \& Steiner, P. (1954). Optimal advertising and optimal quality. The American Economic Review, 44(5), 826-836. 
Echavarría, J., Arbeláez, M., \& Rosales, M. (2006). La productividad y sus determinantes: el caso de la industria colombiana. Desarrollo y Sociedad, 57(1), 77-122. doi:10.13043/dys.57.3

Eng, L., \& Keh, H. (2007). The effects of advertising and brand value on future operating and market performance. Journal of Advertising, 36(4), 91-100. doi:10.2753/JOA0091-3367360407

Ennen, E., \& Richter, A. (2010). The whole is more than the sum of its parts-or is it? A review of the empirical literature on complementarities in organizations. Journal of Management, 36(1), 207-233. doi:10.1177/0149206309350083

Erickson, G. (1992). Empirical analysis of closed-loop duopoly advertising strategies. Management Science, 38(12), 1732-1749. doi:10.1287/mnsc.38.12.1732

Erickson, G., \& Jacobson, R. (1992). Gaining comparative advantage through discretionary expenditures: The returns to $\mathrm{R} \& \mathrm{D}$ and advertising. Management Science, 38(9), 1264-1279. doi:10.1287/mnsc.38.9.1264

Fariñas, J., \& Martín-Marcos, A. (2007). Exporting and Economic Performance: Firm-level Evidence of Spanish Manufacturing. The World Economy, 30(4), 618-646. doi:10.1111/j.1467-9701.2007.01007.x

Fariñas, J., López, A., \& Martín-Marcos, A. (2014). Assessing the impact of domestic outsourcing and offshoring on productivity at the firm level. Applied Economics, 46(15), 1814-1828. doi:10.1080/00036 846.2014.884704

Fombrun, C., Gardberg, N., \& Barnett, M. (2000). Opportunity platforms and safety nets: Corporate citizenship and reputational risk. $\mathrm{Bu}$ siness and society review, 105(1), 85-106. doi:10.1111/0045-3609.00066

Frieder, L., \& Subrahmanyam, A. (2005). Brand perceptions and the market for common stock. Journal of financial and Quantitative Analysis, 40(1), 57-85.

Gupta, S., \& Steenburgh, T. (2008). Allocating marketing resources. (R. A. Marketing Mix Decisions: New Perspectives and Practices, Ed.) Chicago, IL, EEUU: American Marketing Association.

Hall, B., Mairesse, J., \& Mohnen, P. (2010). Measuring the Returns to R\&D. In Handbook of the Economics of Innovation (Vol. 2, pp. 10331082). North-Holland.

Han, B., \& Manry, D. (2004). The value-relevance of R\&D and advertising expenditures: Evidence from Korea. The International Journal of Accounting, 39(2), 155-173. doi:10.1016/j.intacc.2004.02.002

Hanssens, D., Parsons, L., \& Schultz, R. (1999). Market Response Models:Econometric and Time Series Analysis. Boston. MA: Kluwer Academic Publishers.

Hirschey, M. (1982). Intangible capital aspects of advertising and R \& D expenditures. The Journal of Industrial Economics, 34(4), 375-390. doi: $10.2307 / 2097924$
Hoberg, G., \& Phillips, G. (2016). Text-based network industries and endogenous product differentiation. Journal of Political Economy, 124(5), 1423-1465. doi:10.1086/688176

Hofman, A., Mas, M., Aravena, C., \& Fernández de Guevara, J. (2017). Crecimiento económico y productividad en Latinoamérica. El proyecto LA-KLEMS. El trimestre económico, 84(334), 259-306. doi:10.20430/ete.v84i334.302

Jaumandreu, J., \& Mairesse, J. (2017). Disentangling the effects of process and product innovation on cost and demand. Economics of Innovation and New Technology, 26(1-2), 150-167. doi:10.1080/10438599.2016.1205276

Joshi, A., \& Hanssens, D. (2009). Movie advertising and the stock market valuation of studios: a case of "great expectations?". Marketing Science, 28(2), 239-250. doi:10.1287/mksc.1080.0392

Joshi, A., \& Hanssens, D. (2010). The direct and indirect effects of advertising spending on firm value. Journal of Marketing, 74(1), 20-33. doi:10.1509/jmkg.74.1.20

Kihlstrom, R., \& Riordan, M. (1984). Advertising as a Signal. Journal of Political Economy, 92(3), 427-450. doi:10.1086/261235

Kirmani, A., \& Wright, P. (1989). Money talks: Perceived advertising expense and expected product quality. Journal of consumer research, 16(3), 344-353. doi:10.1086/209220

Kirmani, A., \& Zeithaml, V. (1993). Advertising, perceived quality, and brand image. Hillsdale, NJ: Lawrence Erlbaum Associates.

Kor, Y., \& Mahoney, J. (2005). How dynamics, management, and governance of resource deployments influence firm-level performance. Strategic Management Journal, 26(5), 489-496. doi:10.1002/smj.459

Kremer, S., Bijmolt, T., Leeflang, P., \& Wieringa, J. (2008). Generalizations on the effectiveness of pharmaceutical promotional expenditures. International Journal of Research in Marketing, 25(4), 234-246. doi:10.1016/j.ijresmar.2008.08.001

Lambin, J.-J. (1976). Advertising, competition and market conduct in oligopoly over time. Amsterdam: North Holland Publishing, Co.

Leone, R. (1995). Generalizing what is known about temporal aggregation and advertising carryover. Marketing Science, 14(3), G141G150. doi:10.1287/mksc.14.3.g141

Lev, B. (2005). Intangible Assets: Concepts and Measurements. In Encyclopedia of Social Measurement (pp. 299-305). Elsevier Inc.

Levinsohn, J., \& Petrin, A. (2003). Estimating production functions using inputs to control for unobservables. The Review of Economic Studies, 70(2), 317-341. doi:10.1111/1467-937X.00246

López, A. (2014). Outsourcing and firm productivity: a production function approach. Empirical Economics, 47(3), 977-998. doi:10.1007/ s00181-013-0770-X 
Luo, X., \& de Jong, P. (2012). Does advertising spending really work? The intermediate role of analysts in the impact of advertising on firm value. Journal of the Academy of Marketing Science, 40(4), 605-624. doi:10.1007/s11747-010-0240-3

Martin, S. (1979). Advertising, concentration, and profitability: the simultaneity problem. The Bell Journal of Economics, 10(2), 639-647.

Mavrommati, A., \& Papadopoulos, A. (2005). Measuring advertising intensity and intangible capital in the Greek food industry. Applied Economics, 37(15), 1777-1787. doi: 10.1080/00036840500217267

Mela, C., Gupta, S., \& Lehmann, D. (1997). The long-term impact of promotion and advertising on consumer brand choice. Journal of Marketing research, 34(2), 248-261. doi:10.1177/002224379703400205

Mesak, H. (1992). An aggregate advertising pulsing model with wearout effects. Marketing Science, 11(3), 310-326. doi:10.1287/mksc.11.3.310

Milgrom, P., \& Roberts, J. (1986). Price and advertising signals of product quality. Journal of Political Economy, 94(4), 796-821. doi:10.1086/261408

Mizik, N., \& Jacobson, R. (2003). Trading off between value creation and value appropriation: The financial implications of shifts in strategic emphasis. Journal of marketing, 67(1), 63-76. doi:10.1509/jmkg.67.1.63.18595

Mohnen, P., \& Hall, B. (2013). Innovation and productivity: An update. Eurasian Business Review, 3(1), 47-65. doi:10.14208/BF03353817

Narayanan, S., Desiraju, R., \& Chintagunta, P. (2004). Return on investment implications for pharmaceutical promotional expenditures: The role of marketing-mix interactions. Journal of Marketing, 68(4), 90-105. doi:10.1509/jmkg.68.4.90.42734

Netter, J. (1982). Excessive advertising: An empirical analysis. The Journal of Industrial Economics, 30(4), 361-373. doi:10.2307/2097923

Niebel, T., O'Mahony, M., \& Saam, M. (2017). The contribution of intangible assets to sectoral productivity growth in the EU. Review of Income and Wealth, 63(s1), 1-19. doi:10.1111/roiw.12248

Olley, G., \& Pakes, A. (1996). The dynamics of productivity in the telecommunications equipment industry. Econometrica, 64(6), 1263-1297.

Osinga, E., Leeflang, P., Srinivasan, S., \& Wieringa, J. (2011). Why do firms invest in consumer advertising with limited sales response? A shareholder perspective. Journal of Marketing, 75(1), 109-124. doi:10.1509/jm.75.1.109

Petrin, A., \& Levinsohn, J. (2012). Measuring aggregate productivity growth using plant-level data. The RAND Journal of Economics, 43(4), 705-725. doi:10.1111/1756-2171.12005
Porter, M. (1974). Consumer behavior, retailer power and market performance in consumer goods industries. The Review of Economics and Statistics, 56(4), 419-436. doi:10.2307/1924458

Saggi, K. (2002). Trade, foreign direct investment, and international technology transfer: A survey. The World Bank Research Observer, 17(2), 191-235. doi:10.1093/wbro/17.2.191

Salinger, M. (1984). Tobin's q, unionization, and the concentration-profits relationship. The Rand Journal of Economics, 15(2), 159170. doi: $10.2307 / 2555673$

Solano-Solano, J., Camino-Mogro, S., \& Alvarado, M. (2017). Análisis del entorno competitivo en el que operan las MIPYMES del sector manufacturero en Ecuador. Empresarial, 11(44), 53-62.

Srinivasan, R., Lilien, G., \& Sridhar, S. (2011). Should firms spend more on research and development and advertising during recessions? Journal of Marketing, 75(3), 49-65. doi:10.1509/jmkg.75.3.49

Sun, S. (2014). Foreign entry and firm advertising intensity: evidence from China. Review of Industrial Organization, 45(1), 79-97. doi:10.1007/s11151-014-9426-Z

Superintendencia de Compañías, Valores y Seguros del Ecuador. (2018, 06 01). Portal de Información / Societario. Retrieved 06 01, 2018, from Portal de Información / Societario: http://appscvs.supercias.gob.ec/portalInformacion/sector_societario.zul

Sutton, J. (1991). Sunk costs and market structure: Price competition, advertising, and the evolution of concentration. Cambridge, MA: MIT press.

Syverson, C. (2011). What determines productivity? Journal of Economic Literature, 49(2), 326-65. doi:10.1257/jel.49.2.326

Tirole, J. (1988). The theory of industrial organization. London, England: MIT press.

Urata, S., \& Kawai, H. (2002). Technological progress by small and medium enterprises in Japan. Small Business Economics, 18(1-3), 53 67. doi:10.1023/A:1015117509680

Van Beveren, I. (2012). Total factor productivity estimation: a practical review. Journal of Economic Surveys, 26(1), 98-128. doi:10.1111/ j.1467-6419.2010.00631.x

Van Biesebroeck, J. (2007). Robustness of Productivity Estimates. The Journal of Industrial Economics, 55(3), 529-569. doi:10.1111/j.14676451.2007.00322.x

Weiss, L. (1969). Advertising, Profits, and Corporate Taxes. The Review of Economics and Statistics, 51(4), 421-430. doi:10.2307/1926433 Wooldridge, J. (2015). Introductory econometrics: A modern approach (4th ed.). Nelson Education, Ltd., Ohio, USA: Nelson Education, Ltd. 


\section{Annexes}

Table 1A. Sector C: Manufacturing Industries

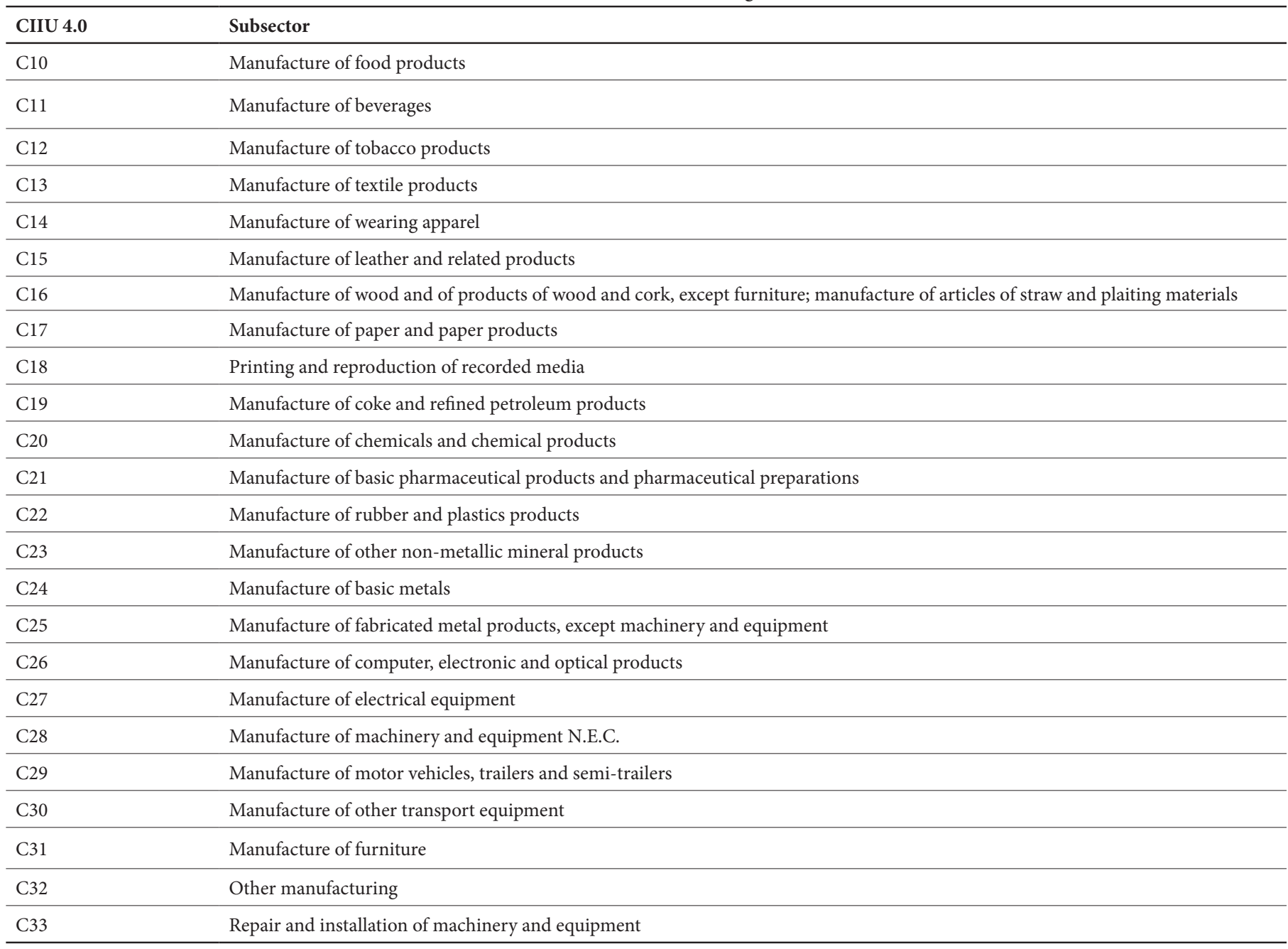

Source: Superintendencia de Compañías, Valores y Seguros; EcuadorianNational Institute os Statistics.

Elaboration: The author 
Table2A. Number of firms incurring in Advertising investments by two-digit ISIC

\begin{tabular}{|c|c|c|c|c|c|c|c|c|c|c|c|c|c|c|c|c|c|c|c|c|c|c|c|c|}
\hline \multirow{2}{*}{ Year } & \multicolumn{24}{|c|}{ Two-Digit ISIC } \\
\hline & 10 & 11 & 12 & 13 & 14 & 15 & 16 & 17 & 18 & 19 & 20 & 21 & 22 & 23 & 24 & 25 & 26 & 27 & 28 & 29 & 30 & 31 & 32 & 33 \\
\hline 2007 & $72 \%$ & $82 \%$ & $100 \%$ & $61 \%$ & $53 \%$ & $70 \%$ & $53 \%$ & $71 \%$ & $58 \%$ & $33 \%$ & $64 \%$ & $77 \%$ & $61 \%$ & $65 \%$ & $71 \%$ & $60 \%$ & $64 \%$ & $72 \%$ & $59 \%$ & $62 \%$ & $29 \%$ & $59 \%$ & $65 \%$ & $49 \%$ \\
\hline 2008 & $67 \%$ & $72 \%$ & $100 \%$ & $58 \%$ & $58 \%$ & $64 \%$ & $51 \%$ & $76 \%$ & $52 \%$ & $58 \%$ & $61 \%$ & $76 \%$ & $56 \%$ & $62 \%$ & $68 \%$ & $43 \%$ & $50 \%$ & $56 \%$ & $43 \%$ & $58 \%$ & $37 \%$ & $60 \%$ & $61 \%$ & $36 \%$ \\
\hline 2009 & $70 \%$ & $73 \%$ & $50 \%$ & $66 \%$ & $64 \%$ & $72 \%$ & $62 \%$ & $67 \%$ & $62 \%$ & $62 \%$ & $66 \%$ & $76 \%$ & $61 \%$ & $72 \%$ & $72 \%$ & $57 \%$ & $52 \%$ & $56 \%$ & $58 \%$ & $75 \%$ & $44 \%$ & $69 \%$ & $52 \%$ & $40 \%$ \\
\hline 2010 & $71 \%$ & $64 \%$ & $100 \%$ & $58 \%$ & $60 \%$ & $70 \%$ & $55 \%$ & $64 \%$ & $53 \%$ & $57 \%$ & $65 \%$ & $77 \%$ & $61 \%$ & $73 \%$ & $62 \%$ & $56 \%$ & $50 \%$ & $65 \%$ & $49 \%$ & $62 \%$ & $45 \%$ & $62 \%$ & $57 \%$ & $40 \%$ \\
\hline 2011 & $65 \%$ & $58 \%$ & $100 \%$ & $60 \%$ & $64 \%$ & $66 \%$ & $56 \%$ & $55 \%$ & $61 \%$ & $65 \%$ & $62 \%$ & $76 \%$ & $62 \%$ & $69 \%$ & $65 \%$ & $51 \%$ & $53 \%$ & $67 \%$ & $56 \%$ & $62 \%$ & $59 \%$ & $63 \%$ & $62 \%$ & $40 \%$ \\
\hline 2012 & $59 \%$ & $53 \%$ & $60 \%$ & $55 \%$ & $57 \%$ & $57 \%$ & $42 \%$ & $55 \%$ & $48 \%$ & $53 \%$ & $55 \%$ & $67 \%$ & $50 \%$ & $60 \%$ & $54 \%$ & $42 \%$ & $52 \%$ & $56 \%$ & $48 \%$ & $53 \%$ & $34 \%$ & $55 \%$ & $43 \%$ & $35 \%$ \\
\hline 2013 & $49 \%$ & $55 \%$ & $50 \%$ & $51 \%$ & $58 \%$ & $54 \%$ & $43 \%$ & $46 \%$ & $46 \%$ & $68 \%$ & $53 \%$ & $64 \%$ & $48 \%$ & $54 \%$ & $44 \%$ & $42 \%$ & $41 \%$ & $49 \%$ & $44 \%$ & $47 \%$ & $28 \%$ & $55 \%$ & $42 \%$ & $35 \%$ \\
\hline 2014 & $62 \%$ & $60 \%$ & $75 \%$ & $62 \%$ & $64 \%$ & $70 \%$ & $45 \%$ & $56 \%$ & $51 \%$ & $65 \%$ & $58 \%$ & $74 \%$ & $57 \%$ & $59 \%$ & $57 \%$ & $49 \%$ & $47 \%$ & $59 \%$ & $43 \%$ & $59 \%$ & $33 \%$ & $65 \%$ & $43 \%$ & $34 \%$ \\
\hline 2015 & $64 \%$ & $66 \%$ & $50 \%$ & $60 \%$ & $64 \%$ & $66 \%$ & $55 \%$ & $57 \%$ & $52 \%$ & $62 \%$ & $65 \%$ & $75 \%$ & $59 \%$ & $63 \%$ & $60 \%$ & $48 \%$ & $48 \%$ & $63 \%$ & $51 \%$ & $58 \%$ & $47 \%$ & $54 \%$ & $51 \%$ & $36 \%$ \\
\hline 2016 & $65 \%$ & $58 \%$ & $67 \%$ & $59 \%$ & $60 \%$ & $61 \%$ & $50 \%$ & $57 \%$ & $49 \%$ & $52 \%$ & $59 \%$ & $74 \%$ & $55 \%$ & $63 \%$ & $56 \%$ & $45 \%$ & $39 \%$ & $61 \%$ & $44 \%$ & $56 \%$ & $44 \%$ & $58 \%$ & $48 \%$ & $34 \%$ \\
\hline 2017 & $65 \%$ & $60 \%$ & $67 \%$ & $59 \%$ & $61 \%$ & $55 \%$ & $50 \%$ & $60 \%$ & $49 \%$ & $63 \%$ & $62 \%$ & $79 \%$ & $59 \%$ & $59 \%$ & $53 \%$ & $47 \%$ & $50 \%$ & $54 \%$ & $44 \%$ & $60 \%$ & $39 \%$ & $62 \%$ & $67 \%$ & $31 \%$ \\
\hline
\end{tabular}

Source: Superintendencia de Compañías, Valores y Seguros

Elaboration: The author

Table 3A. Total number of firms by two-digit ISIC

\begin{tabular}{|c|c|c|c|c|c|c|c|c|c|c|c|c|c|c|c|c|c|c|c|c|c|c|c|c|}
\hline \multirow{2}{*}{ Year } & \multicolumn{24}{|c|}{ Two-Digit ISIC } \\
\hline & 10 & 11 & 12 & 13 & 14 & 15 & 16 & 17 & 18 & 19 & 20 & 21 & 22 & 23 & 24 & 25 & 26 & 27 & 28 & 29 & 30 & 31 & 32 & 33 \\
\hline 2007 & 274 & 44 & 2 & 98 & 77 & 30 & 38 & 45 & 135 & 6 & 156 & 52 & 140 & 84 & 38 & 89 & 14 & 29 & 41 & 37 & 7 & 63 & 34 & 113 \\
\hline 2008 & 358 & 68 & 2 & 111 & 112 & 39 & 45 & 55 & 164 & 12 & 204 & 76 & 182 & 112 & 50 & 127 & 18 & 39 & 60 & 50 & 16 & 75 & 44 & 191 \\
\hline 2009 & 447 & 88 & 2 & 137 & 115 & 43 & 52 & 66 & 178 & 13 & 221 & 79 & 203 & 121 & 57 & 136 & 23 & 43 & 64 & 53 & 16 & 95 & 44 & 185 \\
\hline 2010 & 495 & 94 & 2 & 154 & 151 & 63 & 60 & 75 & 217 & 14 & 255 & 88 & 223 & 136 & 63 & 159 & 26 & 46 & 71 & 58 & 22 & 108 & 53 & 240 \\
\hline 2011 & 516 & 88 & 3 & 146 & 159 & 68 & 70 & 82 & 226 & 17 & 265 & 92 & 218 & 138 & 69 & 168 & 32 & 52 & 75 & 64 & 22 & 111 & 47 & 257 \\
\hline 2012 & 564 & 88 & 5 & 164 & 179 & 74 & 73 & 85 & 250 & 19 & 289 & 106 & 231 & 151 & 67 & 191 & 42 & 64 & 91 & 66 & 32 & 110 & 54 & 302 \\
\hline 2013 & 450 & 85 & 4 & 134 & 144 & 65 & 69 & 68 & 222 & 19 & 229 & 72 & 177 & 126 & 54 & 184 & 49 & 63 & 103 & 60 & 25 & 94 & 50 & 297 \\
\hline 2014 & 554 & 89 & 4 & 163 & 165 & 70 & 78 & 88 & 231 & 23 & 279 & 102 & 221 & 155 & 70 & 196 & 55 & 71 & 101 & 76 & 27 & 107 & 54 & 296 \\
\hline 2015 & 562 & 90 & 4 & 157 & 172 & 70 & 69 & 84 & 236 & 21 & 304 & 106 & 221 & 160 & 67 & 193 & 48 & 65 & 100 & 77 & 30 & 105 & 53 & 309 \\
\hline 2016 & 578 & 89 & 3 & 155 & 177 & 67 & 72 & 80 & 209 & 21 & 310 & 109 & 217 & 143 & 68 & 207 & 54 & 66 & 108 & 73 & 32 & 106 & 56 & 290 \\
\hline 2017 & 503 & 80 & 3 & 138 & 153 & 55 & 62 & 70 & 171 & 19 & 281 & 99 & 194 & 112 & 59 & 176 & 48 & 63 & 90 & 67 & 28 & 79 & 49 & 262 \\
\hline
\end{tabular}

Source: Superintendencia de Compañías, Valores y Seguros

Elaboration: The author 
Table 4A. Advertising Spending Firms by year

\begin{tabular}{|c|c|c|c|c|c|c|c|c|c|c|c|}
\hline & 2007 & 2008 & 2009 & 2010 & 2011 & 2012 & 2013 & 2014 & 2015 & 2016 & 2017 \\
\hline Advertising Spending Firms & $63 \%$ & $58 \%$ & $64 \%$ & $61 \%$ & $60 \%$ & $52 \%$ & $48 \%$ & $56 \%$ & $58 \%$ & $56 \%$ & $56 \%$ \\
\hline Non-Advertising Spending Firms & $37 \%$ & $42 \%$ & $36 \%$ & $39 \%$ & $40 \%$ & $48 \%$ & $52 \%$ & $44 \%$ & $42 \%$ & $44 \%$ & $44 \%$ \\
\hline
\end{tabular}

Source: Superintendencia de Compañías, Valores y Seguros

Elaboration: The author

Table 5A. Firm's distribution by region

\begin{tabular}{ccccc}
\hline & Costa & Sierra & Oriente & Insular \\
\hline Advertising Spending Firms & 1,504 & 2,296 & 20 & 3 \\
Non-Advertising Spending Firms & 914 & 606 & 27 & 5 \\
Total & 2,418 & 2,902 & 47 & 5 \\
\hline
\end{tabular}

Source: Superintendencia de Compañías, Valores y Seguros

Elaboration: The author 